\title{
Mineral Resources of the Honeycombs Wilderness Study Area, Washakie County, Wyoming
}
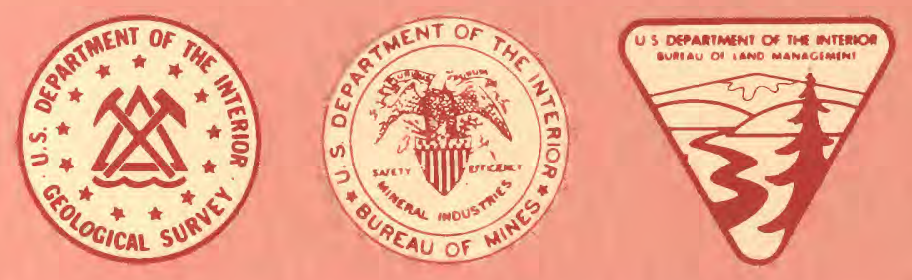

\section{U.S. GEOLOGICAL SURVEY BULLETIN 1756-C}

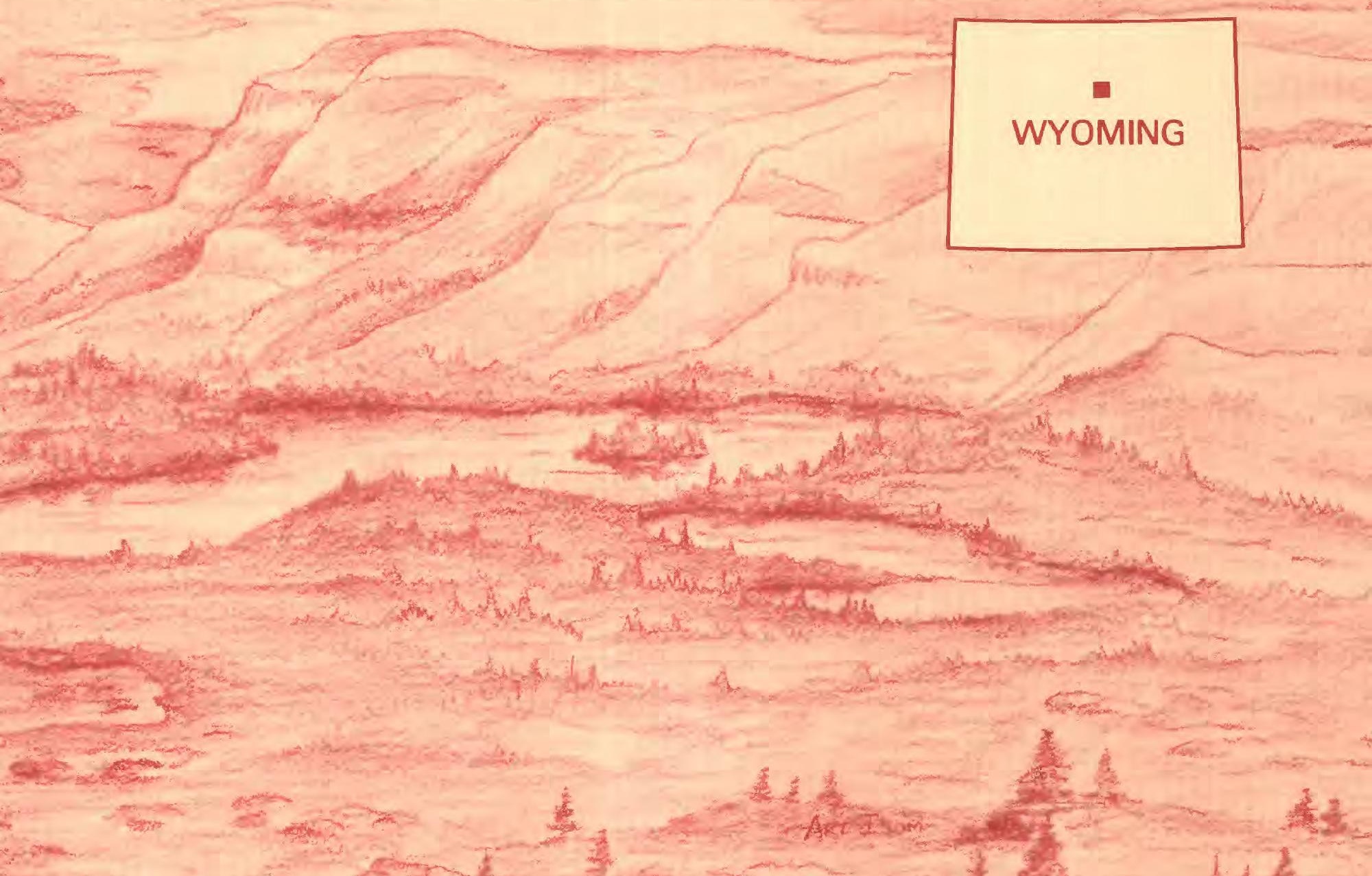




\section{AVAILABILITY OF BOOKS AND MAPS OF THE U.S. GEOLOGICAL SURVEY}

Instructions on ordering publications of the U.S. Geological Survey, along with prices of the last offerings, are given in the current-year issues of the monthly catalog "New Publications of the U.S. Geological Survey." Prices of available U.S. Geological Survey publications released prior to the current year are listed in the most recent annual "Price and Availability List." Publications that are listed in various U.S. Geological Survey catalogs (see back inside cover) but not listed in the most recent annual "Price and Availability List" are no longer available.

Prices of reports released to the open files are given in the listing "U.S. Geological Survey Open-File Reports, "updated monthly, which is for sale in microfiche from the U.S. Geological Survey, Books and Open-File Reports Section, Federal Center, Box 25425, Denver, CO 80225. Reports released through the NTIS may be obtained by writing to the National Technical Information Service, U.S. Department of Commerce, Springfield, VA 22161; please include NTIS report number with inquiry.

Order U.S. Geological Survey publications by mail or over the counter from the offices given below.

\section{BY MAIL}

\section{Books}

Professional Papers, Bulletins, Water-Supply Papers, Techniques of Water-Resources Investigations, Circulars, publications of general interest (such as leaflets, pamphlets, booklets), single copies of Earthquakes \& Volcanoes, Preliminary Determination of Epicenters, and some miscellaneous reports, including some of the foregoing series that have gone out of print at the Superintendent of Documents, are obtainable by mail from

\section{U.S. Geological Survey, Books and Open-File Reports Federal Center, Box 25425 Denver, CO 80225}

Subscriptions to periodicals (Earthquakes \& Volcanoes and Preliminary Determination of Epicenters) can be obtained ONLY from the

\section{Superintendent of Documents \\ Government Printing Orfice \\ Washington, D.C. 20402}

(Check or money order must be payable to Superintendent of Documents.)

\section{Maps}

For maps, address mail orders to

\section{U.S. Geological Survey, Map Distribution \\ Federal Center, Box 25286 \\ Denver, CO 80225}

Residents of Alaska may order maps from

\author{
Alaska Distribution Section, U.S. Geological Survey, \\ New Federal Building - Box 12 \\ 101 Twelfth Ave, Fairbanks, AK 99701
}

\section{OVER THE COUNTER}

\section{Books}

Books of the U.S. Geological Survey are available over the counter at the following Geological Survey Public Inquiries Offices, all of which are authorized agents of the Superintendent of Documents:

- WASHINGTON, D.C.--Main Interior Bldg., 2600 corridor, 18 th and C Sts., NW.

- DENVER, Colorado--Federal Bldg., Rm. 169, 1961 Stout St.

- LOS ANGELES, Callfornia--Federal Pldg., Rm. 7638,300 N. Los Angeles St.

- MENLO PARK, Callfornia--Bldg. 3 (Stop 533), Rm. 3128, 345 Middlefield Rd.

- RESTON, Virginia--503 National Center, Rm. 1C402, 12201 Sunrise Valley Dr.

- SALT LAKE CITY, Utah--Federal Bldg., Rm. 8105, 125 South State St.

- SAN FRANCISCO, California--Customhouse, Rm. 504, 555 Battery St.

- SPOKANE, Washington--U.S. Courthouse, Rm. 678, West 920 Riverside Ave.

- ANCHORAGE, Alaska--Rm. 101, 4230 University Dr.

- ANCHORAGE, Alaska--Federal Bldg, Rm. E-146, 701 C St.

\section{Maps}

Maps may be purchased over the counter at the U.S. Geological Survey offices where books are sold (all addresses in above list) and at the following Geological Survey offices:

- ROLLA, Missouri--1400 Independence Rd.

- DENVER, Colorado--Map Distribution, Bldg. 810, Federal Center

- FAIRBANKS, Alaska--New Federal Bldg., 101 Twelfth Ave. 
Chapter C

\section{Mineral Resources of the Honeycombs Wilderness Study Area, Washakie County, Wyoming}

By JOHN D. PEPER, RANDALL H. HILL, and DOLORES M. KULIK U.S. Geological Survey

CARL L. ALMQUIST

U.S. Bureau of Mines 


\title{
DEPARTMENT OF THE INTERIOR DONALD PAUL HODEL, Secretary
}

\author{
U.S. GEOLOGICAL SURVEY
}

Dallas L. Peck, Director

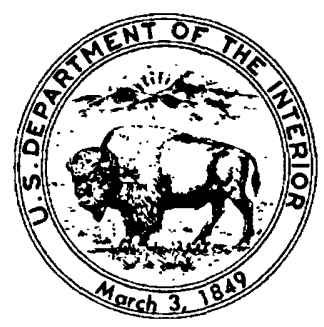

UNITED STATES GOVERNMENT PRINTING OFFICE: 1988

For sale by the

Books and Open-File Reports Section

U.S. Geological Survey

Federal Center, Box 25425

Denver, CO 80225

Any use of trade names in this report is for descriptive purposes only and does not imply endorsement by the U.S. Geological Survey and U.S. Bureau of Mines.

\section{Library of Congress Cataloging-in-Publication Data}

Mineral resources of the Honeycombs Wilderness Study Area, Washakie

County, Wyoming.

(Mineral resources of wilderness study areas-northern Wyoming ; ch. C)

(U.S. Geological Survey bulletin ; 1756)

Bibliography: $p$.

Supt. of Docs. no.: I 19.3:1756

1. Mines and mineral resources-Wyoming-Honeycombs

Wilderness. 2. Honeycombs Wilderness (Wyo.) I. Peper, John

D. II. Series. III. Series: U.S. Geological Survey bulletin ; 1756-C.

QE75.89 no. $1756-C \quad 557.3$ s [553'.09787'34] 88-600317

[TN24.W8] 


\section{STUDIES RELATED TO WILDERNESS}

\section{Bureau of Land Management Wilderness Study Areas}

The Federal Land Policy and Management Act (Public Law 94-579, October 21, 1976) requires the U.S. Geological Survey and the U.S. Bureau of Mines to conduct mineral surveys on certain areas to determine the mineral values, if any, that may be present. Results must be made available to the public and be submitted to the President and the Congress. This report presents the results of a mineral survey of the Honeycombs (WY-010-221) Wilderness Study Area, Washakie County, Wyoming. 
. 


\section{CONTENTS}

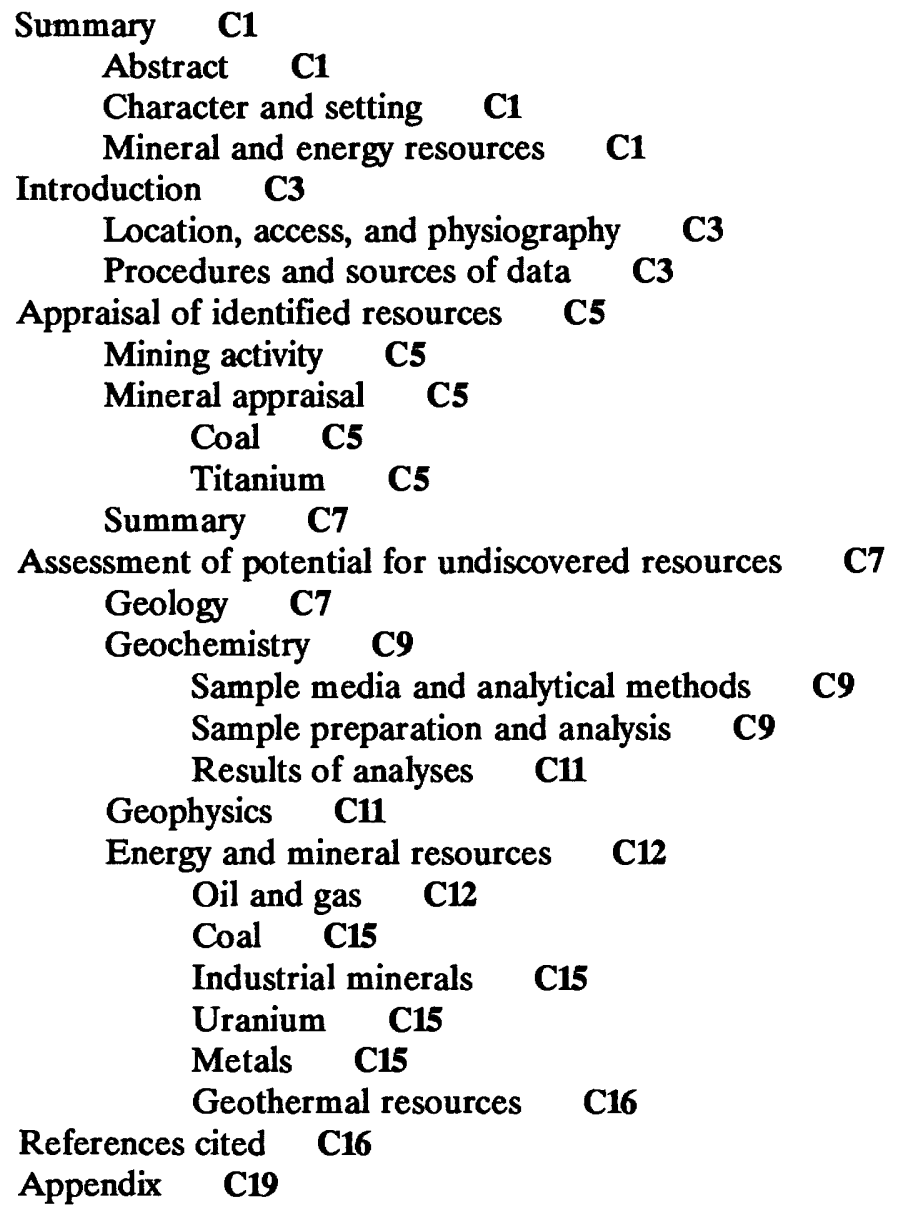

1-7. Maps of the Honeycombs Wilderness Study Area showing:

1. Mineral resource potential C2

2. Location C4

3. Known Geologic Structures, oil and gas drill holes, and lands under lease for oil and gas

4. U.S. Bureau of Mines sample localities, lands under coal-lease application, and coal mines $\mathbf{C 8}$

5. Bedrock geology C10

6. Complete Bouguer gravity anomaly and generalized structure $\mathbf{C 1 3}$

7. Residual intensity magnetic anomaly and generalized structure C14 


\section{TABLES}

1. Coal analyses for as-received samples from the Honeycombs Wilderness Study Area and adjacent coal lease application area W-77322

2. Selected analytical data for U.S. Bureau of Mines stream-sediment samples from the Honeycombs Wilderness Study Area C5 


\title{
Mineral Resources of the Honeycombs Wilderness Study Area, Washakie County, Wyoming
}

\author{
By John D. Peper, Randall H. Hill, and \\ Dolores M. Kulik \\ U.S. Geological Survey
}

Carl L. Almquist

U.S. Bureau of Mines

\section{SUMMARY}

\begin{abstract}
The Honeycombs (WY-010-221) Wilderness Study Area, in Washakie County, Wyo., has no identified mineral or energy resources. There is moderate resource potential for undiscovered oil and gas, for undiscovered subsurface coal in the northeastern and southeastern parts of the study area, and for the industrial commodities sand and gravel, mudstone, and sandstone along the western and northern edges of the study area (fig. 1). The entire wilderness study area has low resource potential for undiscovered uranium and no known resource potential for any undiscovered metals or for geothermal energy, based on existing data. The potential for subsurface titanium placers is unknown.
\end{abstract}

\section{Character and Setting}

The Honeycombs Wilderness Study Area is about 15 mi (miles) east-southeast of Worland, Wyo., the nearest major town. The smaller town of Ten Sleep lies about $8 \mathrm{mi}$ to the east-northeast. Badlands, with pseudokarst depressions called "honeycombs," in the upland heads of numerous gulleys characterize the central and western parts of the study area; benchlands of terrace-gravel remnants and canyon-incised tablelands characterize some of the eastern part of the study area. In the semiarid climate of the study area, vegetation, consisting of grasses and shrubs, is common in the valleys and sparse in the uplands. Elevations

Manuscript approved for publication June 21, 1988. range between 4,800 and $5,600 \mathrm{ft}$ (feet) above sea level. The study area lies in the southeastern part of the Bighorn Basin, mostly within the margin of outcrop of Tertiary strata (see geologic time chart in Appendix for explanation of rock ages). Rocks of the Fort Union Formation and remnants of the Willwood Formation dip gently west in an area of arcuate strike that is concave to the west. The Tensleep fault lies to the north of the study area, and the Bud Kimball anticline lies 6 mi east of the study area. The lower part of the Fort Union is sandy and contains lenticular channel sandstones and mudstones, and lenticular coal beds. Upper parts of the Fort Union Formation and the Willwood remnants consist largely of fine-grained clastic rocks. The Fort Union unconformably overlies the Upper Cretaceous Lance Formation, which in turn overlies a succession of Mesozoic and Paleozoic sedimentary rocks that is very thick here because the study area is near the axis of the Bighorn Basin. Surficial deposits include older fluvial boulder and pebble gravels in benchlands, fan remnants, and terraces at elevations of $4,900-5,100 \mathrm{ft}$, and some dune-sand veneer in the extreme eastern part of the study area, as well as recent sand and gravel in terraces and as active alluvium in streams.

\section{Mineral and Energy Resources}

The only significant mineral-related activity in the Honeycombs Wilderness Study Area has been exploration for oil and gas. Twenty post-FLPMA (Federal Land Policy and Management Act of 1976) leases cover 6,018 acres, and five pre-FLPMA leases cover an additional 2,244 acres (U.S. 


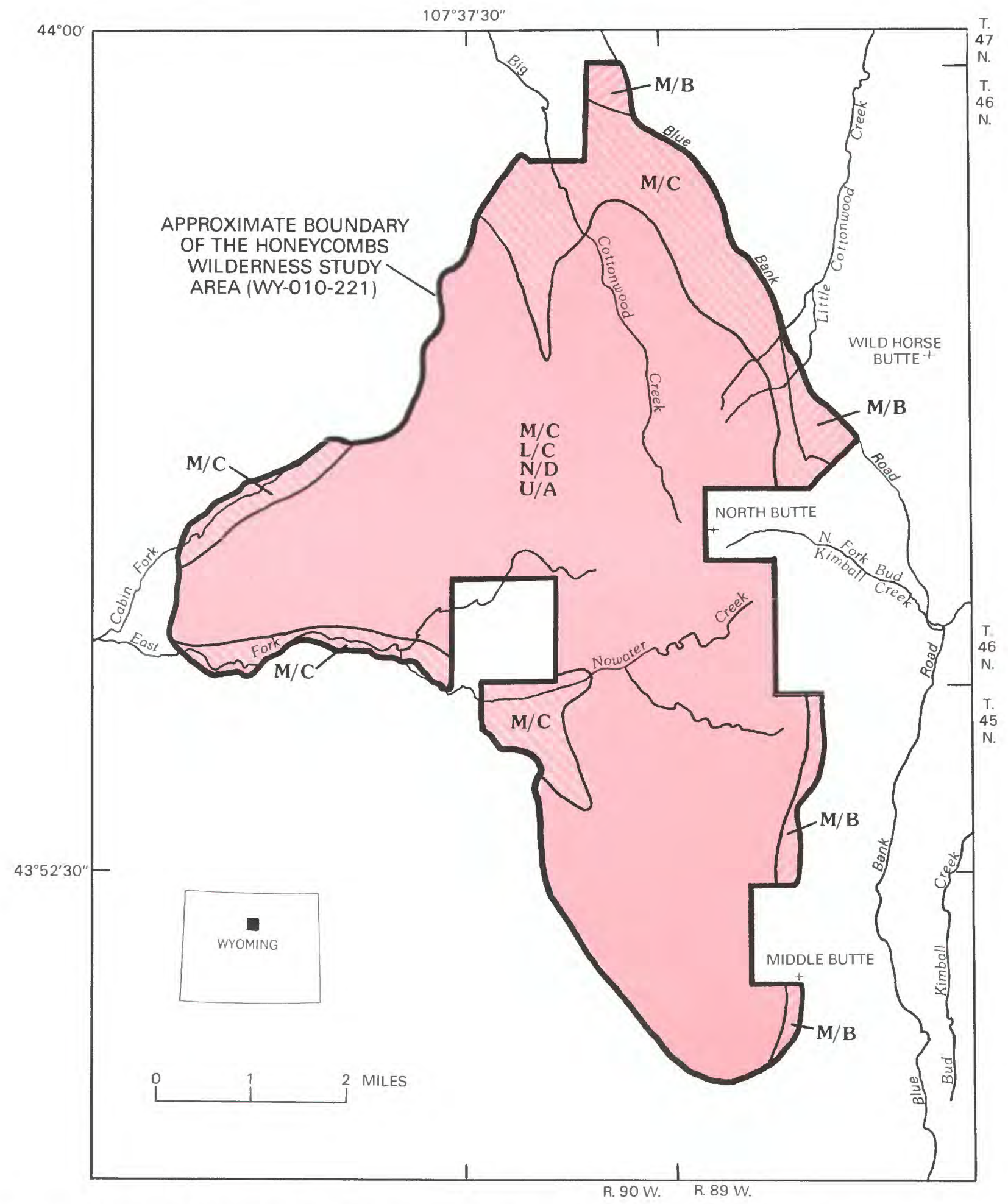

Figure 1 (above and facing page). Mineral resource potential of the Honeycombs Wilderness Study Area, Washakie County, Wyoming.

Bureau of Land Management, 1986) of the study area. Three test wells were drilled in the study area; two were dry holes and one had a show of oil. The southeastern boundary of the Cottonwood Creek oil field, a known Geologic Structure of the BLM (U.S. Bureau of Land Management), is $2 \mathrm{mi}$ northwest of the study area. The northwestern edge of the Bud Kimball oil field (a Known Geologic Structure), which includes a plugged and abandoned well, is near the southeastern boundary. Geologic evidence suggests that there is moderate resource potential for undiscovered oil and 


\section{EXPLANATION}

\begin{tabular}{|c|c|}
\hline $\mathrm{M} / \mathrm{B}$ & $\begin{array}{l}\text { Geologic terrane having moderate mineral resource poten- } \\
\text { tial for coal, with certainty level B }\end{array}$ \\
\hline $\mathrm{M} / \mathrm{C}$ & $\begin{array}{l}\text { Geologic terrane having moderate mineral resource poten- } \\
\text { tial for sand and gravel, mudstone, and sandstone, with } \\
\text { certainty level C }\end{array}$ \\
\hline $\mathrm{M} / \mathrm{C}$ & $\begin{array}{l}\text { Geologic terrane having moderate resource potential for oil } \\
\text { and gas, with certainty level C-Applies to entire }\end{array}$ \\
\hline $\mathrm{L} / \mathrm{C}$ & $\begin{array}{l}\text { Geologic terrane having low mineral resource potential for } \\
\text { uranium, with certainty level C-Applies to entire } \\
\text { study area }\end{array}$ \\
\hline $\mathbf{N} / \mathrm{D}$ & $\begin{array}{l}\text { Geologic terrane having no mineral resource potential for } \\
\text { any metals other than uranium and subsurface ti- } \\
\text { tanium, nor for geothermal energy, with certainty level } \\
\text { D-Applies to entire study area }\end{array}$ \\
\hline$U / A$ & $\begin{array}{l}\text { Geologic terrane having unknown potential for subsurface } \\
\text { titanium, with certainty level A-Applies to entire } \\
\text { study area } \\
\text { Certainty levels }\end{array}$ \\
\hline A & $\begin{array}{l}\text { Available data are not adequate to determine the level of } \\
\text { mineral potential }\end{array}$ \\
\hline B & $\begin{array}{l}\text { Available information suggests the level of mineral } \\
\text { resource potential }\end{array}$ \\
\hline C & $\begin{array}{l}\text { Available information gives a good indication of the level } \\
\text { of mineral resource potential }\end{array}$ \\
\hline D & $\begin{array}{l}\text { Available information clearly defines the level of mineral } \\
\text { resource potential }\end{array}$ \\
\hline
\end{tabular}

gas underneath the study area in: (1) small stratigraphic traps possibly related to facies changes within the Lower Permian Phosphoria or Park City Formations; (2) small fractureinduced porosity traps related to movement on the Tensleep fault and ancillary faults; and (3) possible domal traps in the Tensleep Sandstone. Data are insufficient to identify and pinpoint the location of specific economic accumulations of oil and gas.

Exploration and mining for coal near the study area include a pending application for lease at the northern boundary of the study area, four historic underground mines east of the study area, and coal seams east of the study area discovered by a BLM reconnaissance drilling program. Fort Union coals were tested and are considered to be too thin and too impure for consideration as an economic resource. Some cleaner, thicker Mesozoic coal may lie within 30-50 ft of the ground surface near the eastern edges of the study area, but it may increase in depth to thousands of feet below the western part of the study area. The resource potential for undiscovered subsurface coal resources in the northeastern and southeastern parts of the study area is moderate.

The lower part of the Fort Union Formation may contain uranium deposits of the roll-front type. Geochemical sampling and analysis failed to identify significant uranium concentrations, however, and the study area is considered to have low mineral resource potential for uranium. Geologic and geochemical data suggest no mineral resource potential for resources of any other metals in the study area. Although there are mechanical lag concentrations of barite, zircon, rutile, and some ilmenorutile in active stream alluvium in the study area, they are too sparse to constitute potential resources. The geologic environment of the study area suggests a moderate potential for undiscovered resources of sand and gravel, mudstone, and sandstone. The sandstone is considered undesirable for use as dimension stone. There is no resource potential for geothermal energy in the study area. The potential for subsurface placer deposits of titanium is unknown.

\section{INTRODUCTION}

\section{Location, Access, and Physiography}

The U.S. Geological Survey (USGS) and the U.S. Bureau of Mines (USBM) studied the mineral resources of 20,740 acres of the Honeycombs (WY-010-221) Wilderness Study Area in Washakie County, northcentral Wyoming, at the request of the BLM. In this report the area studied is referred to as the "wilderness study area" or "study area."

The study area is about $15 \mathrm{mi}$ east-southeast of Worland and about $8 \mathrm{mi}$ west-southwest of Ten Sleep (fig. 2). The eastern side of the study area is reached via a gravel road, Blue Bank road, which extends south from U.S. Highway 16 east of Worland. Blue Bank road borders the study area on the northeast. Unimproved roads and jeep trails that lead south and west reach the southeastern and northern parts of the study area. The western part of the study area is reached by a gravel road, Mobile road, which extends from Banjo Flats southeast of Worland to near the confluence of Cabin and East Forks of Nowater Creek. From this confluence, unimproved gravel roads and jeep trails lead northeast and southeast to the western parts of the study area. Travel in the study area is mostly via rough jeep trail or on foot.

"The Honeycombs" is the name given locally to the steep, irregular badlands topography developed on the weakly indurated, variably erodable mudstone, siltstone, and sandstone of the gently west and northwest dipping Tertiary Fort Union and Willwood Formations. Small depressions are so abundant near the heads of the numerous small gulleys as to result in a pseudokarst topography in some upland areas. Badlands in the western and southern parts of the study area range from 4,400 to $5,500 \mathrm{ft}$ above sea level. These are drained generally westward by Cabin Fork and Hawks Nest Fork, tributaries to East Fork of Nowater Creek. Benchlands and tablelands at about $4,900-5,200 \mathrm{ft}$ in elevation on the eastern and northeastern perimeter of the study area are drained northward by tributaries to Big Cottonwood Creek or northeastward by tributaries to Little Cottonwood Creek or Bud Kimball Creek.

\section{Procedures and Sources of Data}

This report presents an evaluation of the mineral endowment (identified resources and mineral resource potential) of the study area and is the combined result of 


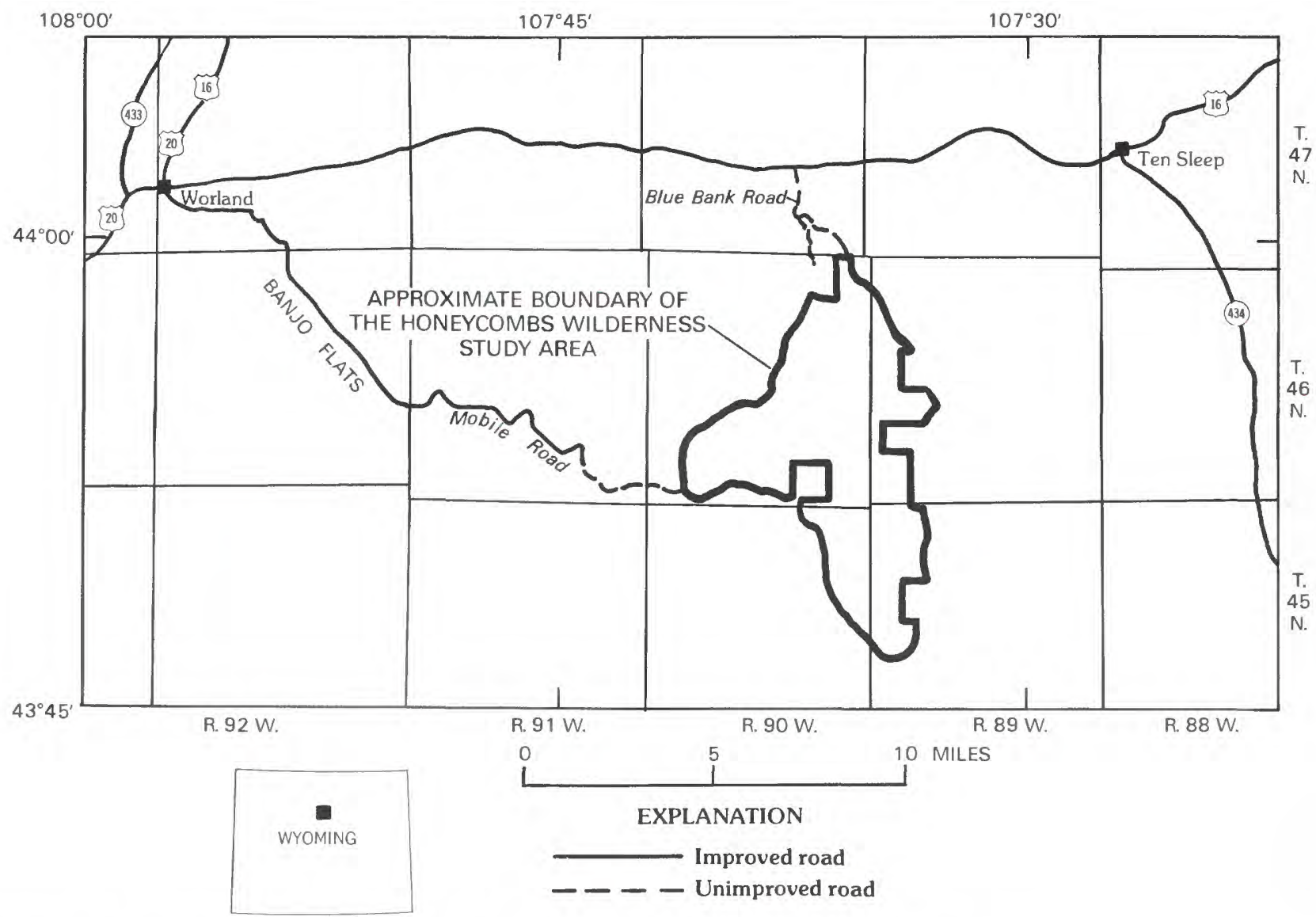

Figure 2. Location of the Honeycombs Wilderness Study Area, Washakie County, Wyoming.

several separate studies by the USBM and the USGS. Identified resources are classified according to the system of the U.S. Bureau of Mines and U.S. Geological Survey (1980), which is shown in the Appendix of this report. Identified resources are studied by the USBM. Mineral resource potential is the likelihood of occurrence of undiscovered metals and nonmetals, industrial rocks and minerals, and of undiscovered energy sources (coal, oil, gas, oil shale, and geothermal energy). It is classified according to the system of Goudarzi (1984) and is shown in the Appendix. Undiscovered resources are studied by the USGS.

The USBM investigation included revicws of literature, land-status records, and BLM files, after which two USBM geologists conducted a 3-day field examination of the study area on foot, by four-wheeldrive vehicle, and by helicopter. Five stream-sediment samples were collected from dry drainages (fig. 3) to investigate a reported geochemical titanium anomaly (U.S. Bureau of Land Management, 1986, p. 45). These samples were analyzed by inductively coupled plasmaatomic emission spectrometry for 33 elements at the USBM Reno Research Center, Reno, Nev. Two coal outcrop samples were collected and submitted to Core
Laboratories, Inc., Denver, Colo., for proximate and ultimate analysis. Complete analytical results are available for public inspection at the USBM Intermountain Field Operations Center, Denver Federal Center, Denver, Colo.

The USGS collected field data and rock and soil samples for geochemical analysis along foot traverses through the study area in June 1986. In September 1986 a detailed stratigraphic section was measured from the top of the Lance Formation through the base of the Willwood Formation along Little Cottonwood Creek and its headwater tributaries west of Green Bug Reservoir. Stream-sediment samples and additional rock samples for geochemical analysis were collected by helicopter from predetermined sites in the major stream basins. A reconnaissance geologic map at $1: 24,000$ scale was compiled by photogeologic techniques from the field data. This map and a measured section (J.D. Peper and R.H. Hill, unpub. data, 1986) augment earlier mapping (scale about 1:200,000) and descriptions of Tertiary rocks in the southeastern Bighorn Basin by Bown (1975) and provided detailed stratigraphic and lithologic control for choosing and evaluating the geochemical sample sites. 
Acknowledgments.-Personnel at the BLM Worland District Office, especially Roger Inmann, Area Manager, and Philip R. Bigsby, Geologist, generously provided information about road access and location, helped secure additional aerial photographic coverage of the study area, and freely contributed their information about the geology of the study area. They provided background information on mineral and oil and gas leases, as well as discussed specific aspects of some rock units in the field.

\section{APPRAISAL OF IDENTIFIED RESOURCES}

\section{By Carl L. Almquist \\ U.S. Bureau of Mines}

\section{Mining Activity}

Coal was mined on a small scale, primarily for local use by ranchers, at four sites within $2 \mathrm{mi}$ of the study area: the Cottonwood Creek mine and Bud Kimball Draw mine, and two sites at the northern end of Big Cedar Ridge (fig. 4). There are no reliable figures, but total production for all of these sites probably did not exceed 1,000 short tons of coal. All are currently idle, but the Cottonwood Creek mine site is under application for lease (Federal coal lease application W-77322). No mines, prospects, or mining claims are in the study area.

\section{Mineral Appraisal}

Mineral commodities of interest near the study area include coal and titanium. Coal deposits occur along the northern and eastern study-area boundaries in the Tertiary Fort Union Formation, in strata that dip gently to the west. Wyoming's largest titaniferous sandstone deposit, a consolidated paleobeach placer in the Mesaverde Formation exposed along Dugout Creek, is $3 \mathrm{mi}$ southeast of the study area.

\section{Coal}

Information on the areal extent of the Fort Union Formation coal beds is lacking. In outcrop, they are very

Table 1. Coal analyses for as-received samples from the Honeycombs Wilderness Study Area, Wyoming, and adjacent coal lease application area $W-77322$

[VM, volatile matter; FC, fixed carbon; FU, average Fort Union Formation coal (Glass and others, 1975, p. 225). Values in percent, except Btu/lb]

\begin{tabular}{ccccccr}
\hline Sample & Moisture & VM & FC & Ash & Sulfur & Btu/lb \\
\hline 1 & 17.01 & 33.83 & 21.82 & 27.34 & 0.77 & 6,187 \\
3 & 17.66 & 35.24 & 26.37 & 20.73 & .42 & 6,684 \\
FU & 14.3 & 34.8 & 42.2 & 9.8 & .6 & 10,150 \\
\hline
\end{tabular}

lenticular. The 5.5-ft-thick bed mined in Bud Kimball Draw, for example, thins along strike to less than $1 \mathrm{ft}$ within $0.25 \mathrm{mi}$ of the mine. The average thickness of these coal beds, including partings, is about $5 \mathrm{ft}$ (Woodruff, 1908). A 3.2-ft-thick coal bed exposed inside the northeastern boundary of the study area (fig. 4, sample loc. 3) contains 8 in. (inches) of solid coal when partings are subtracted (Wood and others, 1983, p. 31), which is too thin for consideration as a resource. In 1984, the BLM drilled four holes near the study area, but they did not investigate coal-bed geometry.

Two outcrop samples collected by the USBM (fig. 4, sample locs. 1, 3) had an average as-received heat value of $6,436 \mathrm{Btu} / \mathrm{lb}$ (Btu per pound) (table 1), but they rank subbituminous $C$ (between 8,300 and $9,500 \mathrm{Btu} / \mathrm{lb}$ ) according to calorific values on a moist, mineral-matterfree basis (American Society for Testing and Materials, 1980, Standard D 388-77). In the Bighorn Basin, Fort Union Formation coals rank subbituminous A or B (between 10,500 and $11,500 \mathrm{Btu} / \mathrm{lb}$ or 9,500 and 10,500 $\mathrm{Btu} / \mathrm{lb}$, respectively), having an average as-received heat value of 10,150 Btu/lb (Glass and others, 1975, p. 225).

An exploratory drill hole on the western boundary of the study area reached coal at depths of 2,690 ft and $3,270 \mathrm{ft}$ in the Mesaverde Formation. Accurate thicknesses and qualitative data for these coal beds are not available. In other Bighorn Basin coal fields, 4- to 6-ft thicknesses are typical, and the rank, with one exception, is subbituminous A or B. The average heat value of these coals, as received, is $10,560 \mathrm{Btu} / \mathrm{lb}$ (Glass and others, 1975, p. 225).

\section{Titanium}

The possibility that titaniferous sandstone deposits may exist in the study area (U.S. Bureau of Land Management, 1986, p. 45) was investigated by the USBM. Five stream-sediment samples (fig. 4, sample locs. 2 and 4-7; table 2) had a mean titanium content of 0.3 percent, the same as for 47 geochemical samples from the vicinity on record at the BLM Worland district office. This titanium content is equivalent to 0.5 percent $\mathrm{TiO}_{2}$, which is not anomalously high. The $\mathrm{TiO}_{2}$ content of average soil ranges from $0.5-1.5$ percent (Miller, 1957 p. 31).

Table 2. Selected analytical data for U.S. Bureau of Mines stream-sediment samples from the Honeycombs Wilderness Study Area, Wyoming

[Detection limits: $\mathrm{Ti}$ and $\mathrm{Fe}, 5 \mathrm{ppm}$ (parts per million) (0.0005 percent); Zr, 20 ppm]

\begin{tabular}{lrcccc}
\hline Sample No. & 2 & 4 & 5 & 6 & 7 \\
Ti (percent) & 0.26 & 0.21 & 0.31 & 0.41 & 0.42 \\
Fe (percent) & .94 & 1.3 & 1.7 & 1.4 & 1.6 \\
Zr (ppm) & 120 & 95 & 120 & 130 & 130 \\
\hline
\end{tabular}




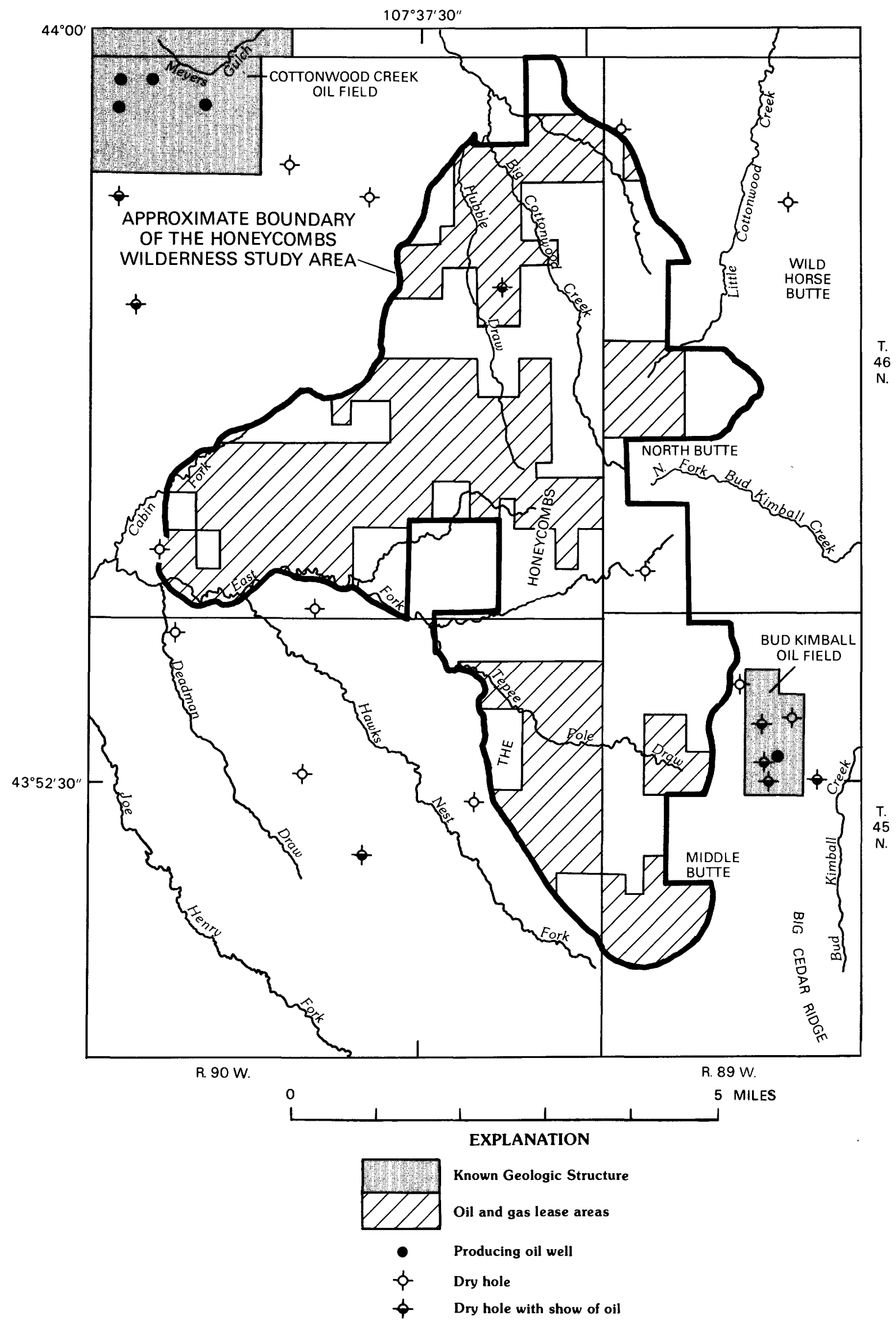


The draft wilderness environmental impact statement for the Washakie Resource Area refers to anomalous Mesaverde sample results that show geochemical similarities with titaniferous deposits to the southeast (U.S. Bureau of Land Management, 1986, p. 45). The Mesaverde Formation is not exposed inside the study area, but it is present at depth. Drilling logs show this formation to be $500 \mathrm{ft}$ below the surface near the eastern boundary and 2,200 $\mathrm{ft}$ below the surface near the western boundary.

\section{Summary}

No identified mineral resources were found in the wilderness study area. Coal exposed inside the boundary is too thin and contains too many impurities to be a resource. The lenticular coal beds mined at sites nearby cannot be projected into the study area, based on available data. Speculation that Mesaverde Formation titaniferous sandstone deposits may occur in the study area is not supported by geochemical or surface geological evidence.

\section{ASSESSMENT OF POTENTIAL FOR UNDISCOVERED RESOURCES}

\section{By John D. Peper, Randall H. Hill, and Dolores M. Kulik U.S. Geological Survey}

\section{Geology}

The Honeycombs Wilderness Study Area lies in the southeastern part of the Bighorn Basin, largely within the margin of outcrop of gently west dipping Tertiary strata (fig. 5). The Tertiary rocks, including the Fort Union Formation and the lower parts of the Willwood Formation in the general area, were described by Bown (1975).

The Fort Union rocks unconformably rest on the Upper Cretaceous Lance Formation along a contact that is broadly arcuate and concave to the west. This contact lies generally $0.1-1.5 \mathrm{mi}$ east of the study area. Along the eastern boundary of the study area, Fort Union rocks dip $3^{\circ}-5^{\circ}$ to the southwest, west, and northwest, progressively

Figure 3 (facing page). Known Geologic Structures, oil and gas drill holes, and lands under lease for oil and gas, in the Honeycombs Wilderness Study Area, Wyoming. Lease and drill-hole information from U.S. Bureau of Land Management (1986). southward along the boundary. These dips decrease to near zero in the central and western parts of the study area. The major nearby geologic structures include the Bud Kimball anticline (Bown, 1975), which strikes northwest and is about $6 \mathrm{mi}$ east of the eastern boundary of the study area, and the Tensleep fault (Allison, 1983, 1984; Love and others, 1978), an east-striking normal fault that was active in Laramide and post-Laramide time. It is $2 \mathrm{mi}$ north of the study area.

A thick succession of Mesozoic and Paleozoic sedimentary rocks (Horn, 1963; Boberg, 1983, p. 12) underlies the Tertiary rocks. Many of these rocks are exposed east and south of the study area (Love and others, 1978). These buried strata include (from youngest to oldest): the Cretaceous Lance, Meeteetse, and Mesaverde Formations, Cody Shale, Frontier Formation, Mowry and Thermopolis Shales, and Cloverly Formation; the Jurassic Morrison, Sundance, and Gypsum Spring Formations; the Triassic Chugwater Formation including the Alcova Limestone Member and the Dinwoody Formation; the Permian Phosphoria and Park City Formations; the Pennsylvanian Tensleep Sandstone and Mississippian, Devonian, Ordovician, and Cambrian strata exist at even greater depths of more than $10,000-12,000 \mathrm{ft}$.

The Upper Cretaceous Lance Formation is present only in the extreme northeastern corner of the study area, where it consists of thin, brown-weathering sheet sandstone, gray and yellow mudstone, bituminous gray shale, and coal. These beds dip locally as much as $24^{\circ}$ to the southwest. Precise biostratigraphic control of the position of the Cretacous-Tertiary boundary has recently been described for rocks about $25 \mathrm{mi}$ to the southwest of the study area, near Cedar Mountain (Hartman, 1986; Larsen, 1988) but has not been established in rocks near the study area, where the uppermost Cretaceous strata are mapped collectively as the Lance and Meeteetse Formations (Love and others, 1978).

The lithology and stratigraphy of the Tertiary rocks, the Fort Union Formation and the overlying Willwood Formation, were described for an area that includes the study area and extends to the south and west of it (Bown, 1975). Details of the biostratigraphic zonation, lateral facies changes within and paleogeographic reconstruction of deposition of these Paleocene and lower Eocene rocks were summarized in later work (Wing and Bown, 1985). The general structural framework for deposition of the Tertiary rocks has been described by Parker and Jones (1983). The name "Polecat Bench Formation" (Jepson, 1940) has been used to refer to rocks otherwise considered Fort Union Formation in the southern part of the Bighorn Basin (Bown, 1975; Hartmann, 1986; Glass and others, 1975). At the base of the Fort Union Formation, in and just east of the study area, are white crossbedded channel 


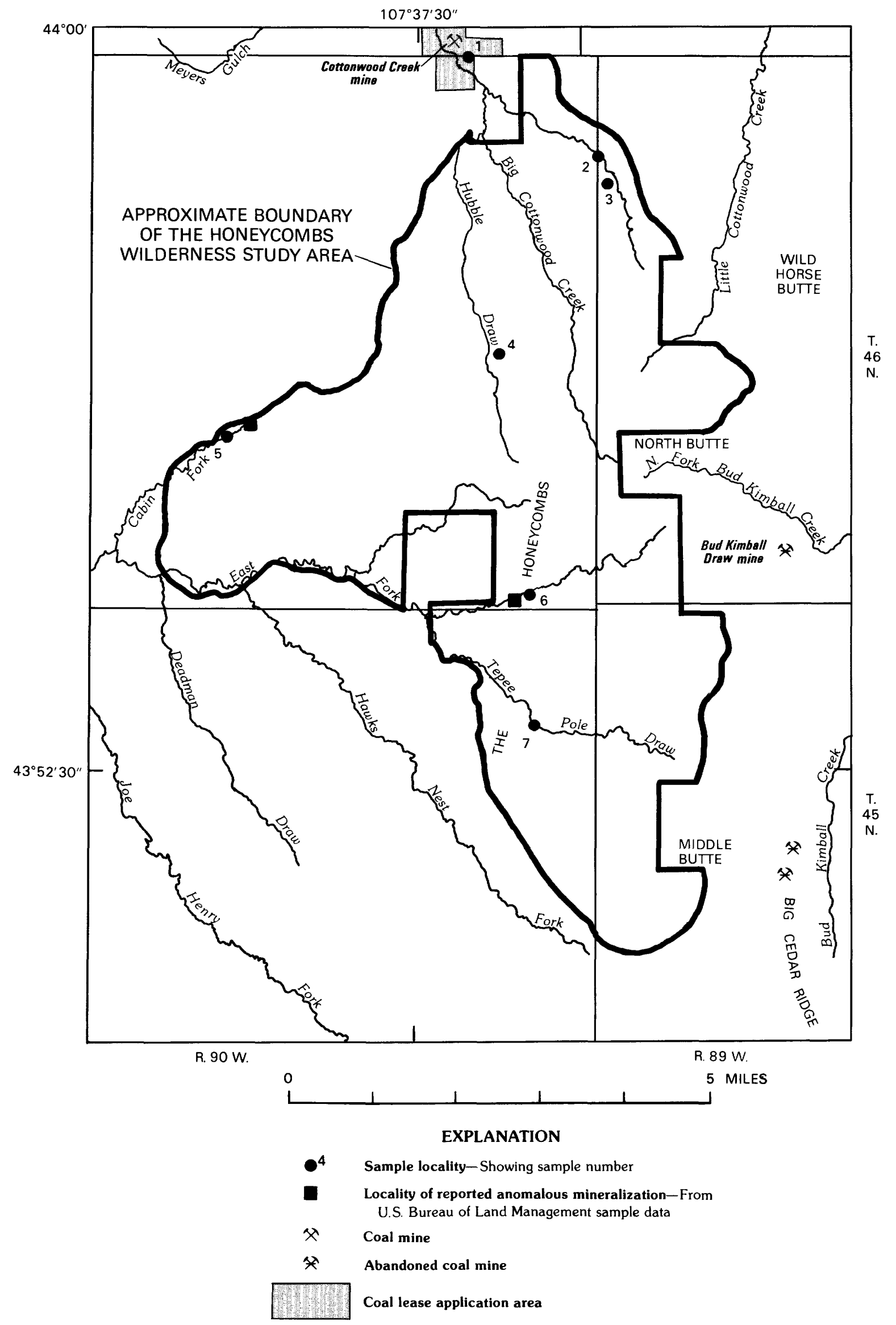


sandstones that are as much as $10-30 \mathrm{ft}$ thick. As noted earlier by Bown (1975), lower and middle parts of the formation (mapped for this study as unit Tfus, fig. 5) are characterized by an abundance of sheet and channel sandstones that intertongue laterally with fine-clastic rocks, including lenticular lignitic shale and coal beds. The upper part of the formation (unit Tfum, fig. 5) consists predominantly of fine-clastic rocks, chiefly drabolive-gray to drab-yellow siltstone and mudstone. Persistent zones, 1-2 ft thick, of ferruginous concretions, thin sandstone, rare thin bituminous shale, and rare thin coal beds, are also present. In a stratigraphic section measured from exposures in the upper reach of Cottonwood Creek (J.D. Peper, unpub. data, 1986), the lower part of the Fort Union is about $430 \mathrm{ft}$ thick, and the upper part is about $760 \mathrm{ft}$ thick.

The Willwood Formation consists predominantly of fine-clastic rocks such as siltstone, mudstone, and shale, and rare thin sandstone beds. Some thick lenses (6-10 ft) of polymictic pebble-conglomerate are present in the upper $70 \mathrm{ft}$ of the Willwood at North Butte. Two thick (15-20 ft), persistent intervals of intensely red siltstone and mudstone identify the lower part and base of the Willwood Formation in the central part of the study area; higher parts of the formation contain olivedrab or yellow-tan siltstone. In the western part of the study area, thinner pale-red mudstone, about $20-30 \mathrm{ft}$ lower in stratigraphic position than the thick, intensely red siltstone to the east, marks the base of the Willwood Formation. About $350 \mathrm{ft}$ of Willwood are exposed at North Butte.

Surficial deposits (not shown on fig. 5) in the Honeycombs Wilderness Study Area include Pliocene and Pleistocene(?) pebble and cobble gravel in older fan and terrace remnants, minor Pleistocene(?) fine sand and silt in dune veneer, and thin deposits of older and recent alluvium, silt, sand, and pebble gravel in the broad lowland reaches of modern intermittent streams. Except for local minor mudflows, upland areas are largely free of any appreciable thickness of surficial deposits. A veneer 8-10 ft thick of older terrace gravel covers the area along Blue Bank road in the northeastern part of the study area, as well as some benchlands at elevations of 4,900-5,000 $\mathrm{ft}$ there. A veneer of fan gravel, now in remnants, was spread northeastward from an apical point east of North Butte, at elevations of 5,100-4,950 ft. Additional remnants of this fan occur just inside the southeastern boundary of the study area. Dune veneer,

Figure 4 (facing page). U.S. Bureau of Mines sample localities, lands under coal-lease application, and coal mines in and near the Honeycombs Wilderness Study Area, Wyoming. From Almquist (1987). less than $15 \mathrm{ft}$ thick, of light-olive-tan silt and fine sand blankets the very northeastern corner of the study area for about $0.25 \mathrm{mi}$ southward along Blue Bank road.

\section{Geochemistry}

\section{Sample Media and Analytical Methods}

Stream sediments were selected as the primary sample medium as they were ultimately derived from a composite of rock and soil exposed in the drainage basin upstream from the sampled sites. Chemical analyses of these stream sediments provide data useful in identifying those basins that contain unusually high concentrations of elements that may be related to mineral occurrences. In addition, studies have shown that heavy-mineral concentrates derived from stream sediments are a useful sample medium in arid-semiarid environments or in areas of rugged topography, where mechanical erosion predominates over chemical erosion (Overstreet and Marsh, 1981; Bugrov and Shalaby, 1975). Thirty-five minus-80-mesh-fraction stream-sediment samples were collected from active alluvium, and 35 heavy-mineral panned concentrate samples were derived from stream sediments.

Two-hundred and six rock samples were collected by ridge traverses across the strike of rocks throughout the study area. Sample localities were spaced to provide general lithologic and areal representation of rock units. The rock samples consisted mostly of chips taken across a measured thickness (generally $6 \mathrm{ft}$ ) of layering or bedding, as well as grab samples of individual rock types. The samples include and represent all rock types in the area, although the number of samples per lithologic type was slightly biased toward tabular sandstone beds and their cemented caps. In addition, 29 fresh and unaltered rock samples were collected to represent the rocks exposed near the stream-sediment sample sites. The actual areal extent of influence of the geochemical information provided by a specific sample is not known; the sampling program was designed only to provide some general information on the geochemical nature of the rock units present.

\section{Sample Preparation and Analysis}

The dry stream-sediment samples were sieved through 80-mesh (0.17-millimeter) stainless-steel sieves. The minus-80-mesh material was retained for analysis and pulverized with ceramic plates to at least minus-100 mesh prior to analysis.

To produce the heavy-mineral concentrate, bulk stream sediment from active alluvium was initially sieved through a 10-mesh (2.0-millimeter) screen. Approxi- 


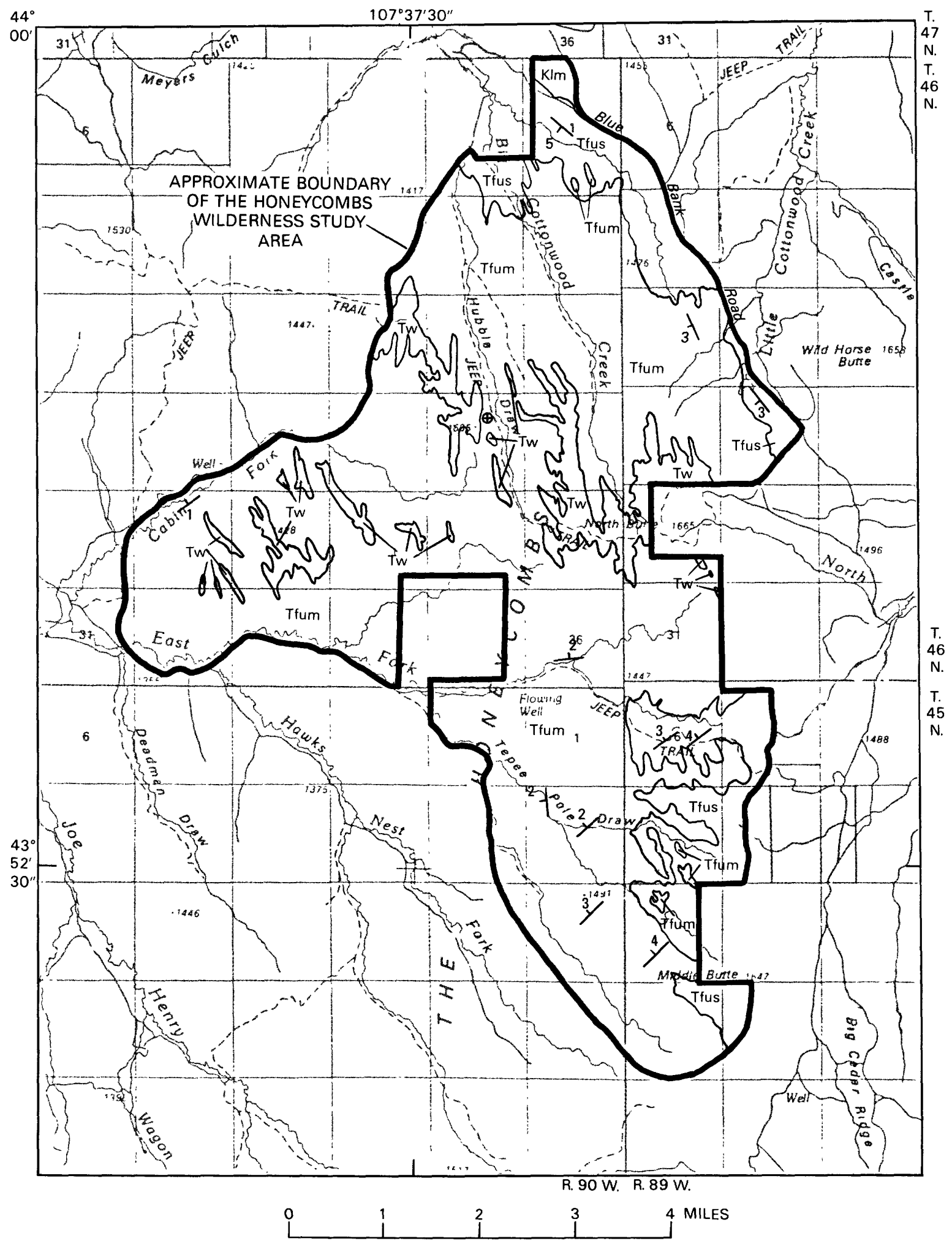

Figure 5 (above and facing page). Generalized geologic map of the Honeycombs Wilderness Study Area, Wyoming. Surficial deposits not shown. Base from U.S. Geological Survey Nowater Creek quadrangle, 1979, scale 1:100,000. Geology mapped by J.D. Peper, 1986.

mately 10-15 pounds of the minus-10-mesh sediment were panned to remove most of the quartz, feldspar, organic materials, and fine silt and clay. The panned concentrate was then separated into light and heavy 


\section{CORRELATION OF MAP UNITS}
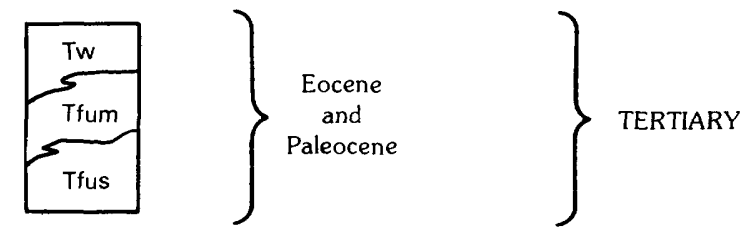

Unconformity
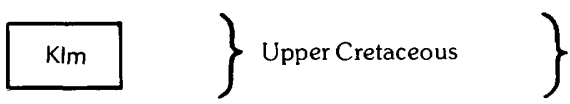

CRETACEOUS

\section{LIST OF MAP UNITS}

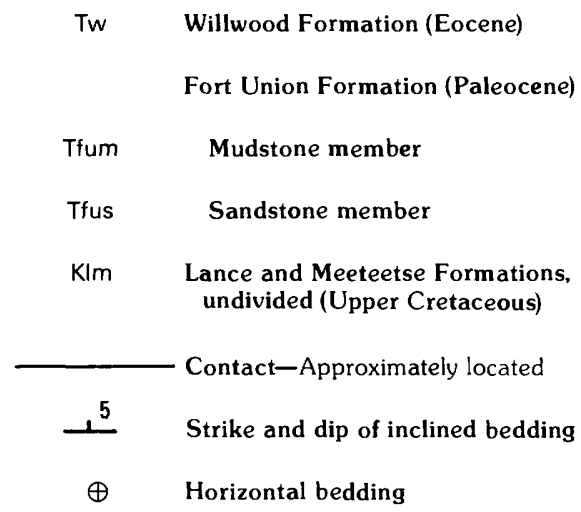

fractions using bromoform (heavy liquid of specific gravity 2.86). The light fraction was discarded. The material of specific gravity greater than 2.8 was further separated into three fractions (highly magnetic, weakly magnetic, and nonmagnetic) using a modified Frantz isodynamic separator. The nonmagnetic fraction was hand ground and saved for analysis. These procedures produce a sample that may contain ore-forming and ore-related minerals such as pyrite, galena, cassiterite, sphalerite, chalcopyrite, stibnite, free gold, barite, and scheelite. The selective concentration of minerals may permit the chemical determination of some elements not easily detected in bulk stream-sediment samples.

Rock samples were crushed and then pulverized to at least minus-100 mesh with ceramic plates prior to analysis.

All three sample media were analyzed for 31 elements using a six-step semiquantitative emission spectrographic method (Grimes and Marranzino, 1968). Due to the limited amount of sample material, the nonmagnetic heavy-mineral concentrates were only analyzed spectrographically. The rock and minus-80-mesh streamsediment samples were also analyzed for arsenic, bismuth, cadmium, antimony, and zinc using inductively coupled argon plasma-atomic emission spectrography (Crock and others, 1987), and for uranium using fluorometric methods (O'Leary and Meier, 1986). A complete listing of all analyses, elements and their lower limits of determination, sample locality map, and rock sample descriptions were assembled (Hill and Peper, unpub. data, 1986).

\section{Results of Analyses}

Threshold values, defined as the upper limit of normal background values, were determined for each element by inspection of element frequency-distribution histograms for all three sample media. A geochemical value higher than the threshold value is considered anomalous and worthy of scrutiny as a possible indication of important mineralization.

Geochemical values for the rock and minus-80mesh stream-sediment samples are well within normal background values with the exception of six rock samples. Two rock samples contained arsenic values of $44 \mathrm{ppm}$ and $17 \mathrm{ppm}$. Fluorapatite, as determined by $\mathrm{X}$-ray diffraction analysis, is the most likely source of the arsenic (Palache and others, 1951), and it is not related to any mineralization. Three rock samples contained uranium values of $4.6 \mathrm{ppm}, 7.4 \mathrm{ppm}$, and $11.0 \mathrm{ppm}$. The source of the uranium is not known; however, the areal extent of the uranium is very limited, as no other rock or stream-sediment samples contained above-threshold values. Only one rock sample contained detectable silver at a value of $0.5 \mathrm{ppm}$.

The nonmagnetic heavy-mineral concentrates contained high concentrations of barium (all samples contained $10,000 \mathrm{ppm}$ or greater), zirconium (all samples contained greater than 2,000 ppm), and titanium (81 percent of the samples contained 2 percent or greater). Barite, zircon, and rutile were identified as the major mineral constituents of the heavy-mineral concentrates by $\mathrm{X}$-ray diffraction analysis. Ilmenorutile was detected by $\mathrm{X}$-ray diffraction in one sample. The barite is considered to be authigenic cement in rock. Barite, zircon, and rutile are believed to be a product of mechanical weathering and erosion of rock, and, as accessory minerals, were concentrated in the active stream alluvium. These minerals were further concentrated by panning. The nominally high strontium values (700-2,000 ppm) may be related to the barite and in small part to another major constituent of the heavymineral concentrate, fluorapatite (as determined by Xray diffraction analysis (Palache and others, 1951)). The yttrium values (150-1,500 ppm) are also likely to be related to the fluorapatite (Palache and others, 1951) and to zircon. The source of detectable tin values in the heavy-mineral concentrate $(20-3,000 \mathrm{ppm})$ is not known.

\section{Geophysics}

Gravity and magnetic studies were made as part of the mineral resource evaluation of the Honeycombs 
Wilderness Study Area. They provide information on the subsurface distribution of rock masses and on the structural framework. The gravity and magnetic data define only regional structural features (figs. 6 and 7).

The observed gravity data were obtained from files maintained by the Defense Mapping Agency of the U.S. Department of Defense (U.S. Defense Mapping Agency, Aerospace Center, 1974). Bouguer anomaly values were computed using the 1967 gravity formula (International Association of Geodesy, 1971) and a reduction density of 2.67 grams per cubic centimeter. Mathematical formulas are in Cordell and others (1982). Terrain corrections were made by computer for a distance of $100 \mathrm{mi}$ from the station using the method of Plouff (1977). A complete Bouguer anomaly gravity map was constructed from the data (fig. 6).

Magnetic data are from U.S. Department of Energy (1982). Flight lines were flown east-west at 2- to 5 -mi intervals at $400-\mathrm{ft}$ elevation above the ground surface. A residual intensity magnetic map was constructed from the data (fig. 7).

The Honeycombs Wilderness Study Area lies astride a gradient between higher gravity values to the northeast, associated with crystalline rocks of the Big Horn uplift, and lower gravity values to the southwest, associated with sedimentary rocks of the Bighorn Basin. This gradient extends at least $70 \mathrm{mi}$ to the northwest of the study area. It coincides generally with the exposed bounding thrust fault of the Bighorn uplift for about 35 $\mathrm{mi}$; this relationship suggests that the fault is present in the subsurface along the entire length of the gravity gradient. The anticlines in the southwestern part of the study area likely are the surface expressions of thrust faults that parallel the bounding thrust at depth. The gravity low in the southwestern part of the map area (fig. 6) indicates that the structurally deepest part of the Bighorn Basin is offset to the southwest from the mapped axis of the basin as defined by well data (Ver Ploeg, 1985). The moderately high gravity deflection (A, fig. 6) west of the study area suggests that high-density rocks (crystalline and (or) Paleozoic) are present in a buried thrust plate beneath sedimentary rocks of the basin at depths approaching $3 \mathrm{mi}$.

A magnetic high coincides with the gravity high and extends northeastward to an area where high magnetic values are associated with crystalline rocks of the Bighorn uplift. The magnetic low over the study area probably reflects a difference in magnetic susceptibility within the crystalline basement rocks, and the northeasttrending gradient probably only reflects the transition between areas of different susceptibility.

\section{Energy and Mineral Resources}

\section{Oil and Gas}

Geologic evidence suggests that there is a moderate resource potential, with certainty level $\mathrm{C}$, for oil and gas in small traps in the subsurface of the Honeycombs Wilderness Study Area. Extrapolation of data and interpretations from nearby structures and oil fields indicate that the subsurface of the study area is favorable for the migration and accumulation of oil in small traps related to: (1) possible facies changes within the Lower Permian Phosphoria or Park City Formations; (2) nodes of fracture-induced porosity related to faulting in subsurface rock in response to movements on the Tensleep fault; and (3) possible domal structures. Data are insufficient to identify and pinpoint the existence of specific economic accumulations of oil and gas in the subsurface rocks of the study area.

The Honeycombs Wilderness Study Area lies in the southeastern part of the Bighorn Basin near many fields (fig. 3) that produce oil and associated gas. The oil and gas potential of the study area was shown as moderate by Spencer and Powers (1982). In the general area, Permian limestone, where present in the subsurface, is the major producing reservoir, having both stratigraphic and structural traps. Pennsylvanian and Cretaceous sandstone is productive in some places. The Cottonwood Creek oil field (a Known Geologic Structure, fig. 3), whose southern border lies about $2 \mathrm{mi}$ northwest of the study area, produced more than 31 million barrels of oil. A much smaller amount was produced from the Bud Kimball oil field (a Known Geologic Structure, fig. 3) whose border lies within $500 \mathrm{ft}$ of the southeastern boundary of the study area (U.S. Bureau of Land Management, 1986, p. 78 and map 16). The cited map also shows three test wells, two dry and one with a show of oil, within the study area. Otherwise the study area has not been extensively test drilled for oil and gas. Oil reservoirs in the nearby Cottonwood Creek oil field were earlier documented as being stratigraphic traps within carbonate facies referred to as part of the Lower Permian Phosphoria Formation by some and the Park City Formation by others, or fault traps in the Tensleep Sandstone (Pedry, 1975). More recently, Allison (1984) noted that both the overall pattern of fracture porosity, on subsidiary or associated faults, and the sites of the facies changes in the Phosphoria Formation may be controlled by ancillary block movements due to movements on the Tensleep fault. The Phosphoria Formation grades generally, from northwest to southeast, from limestone updip down into evaporite beds, and then into redbeds (Burke and Thomas, 1956). 


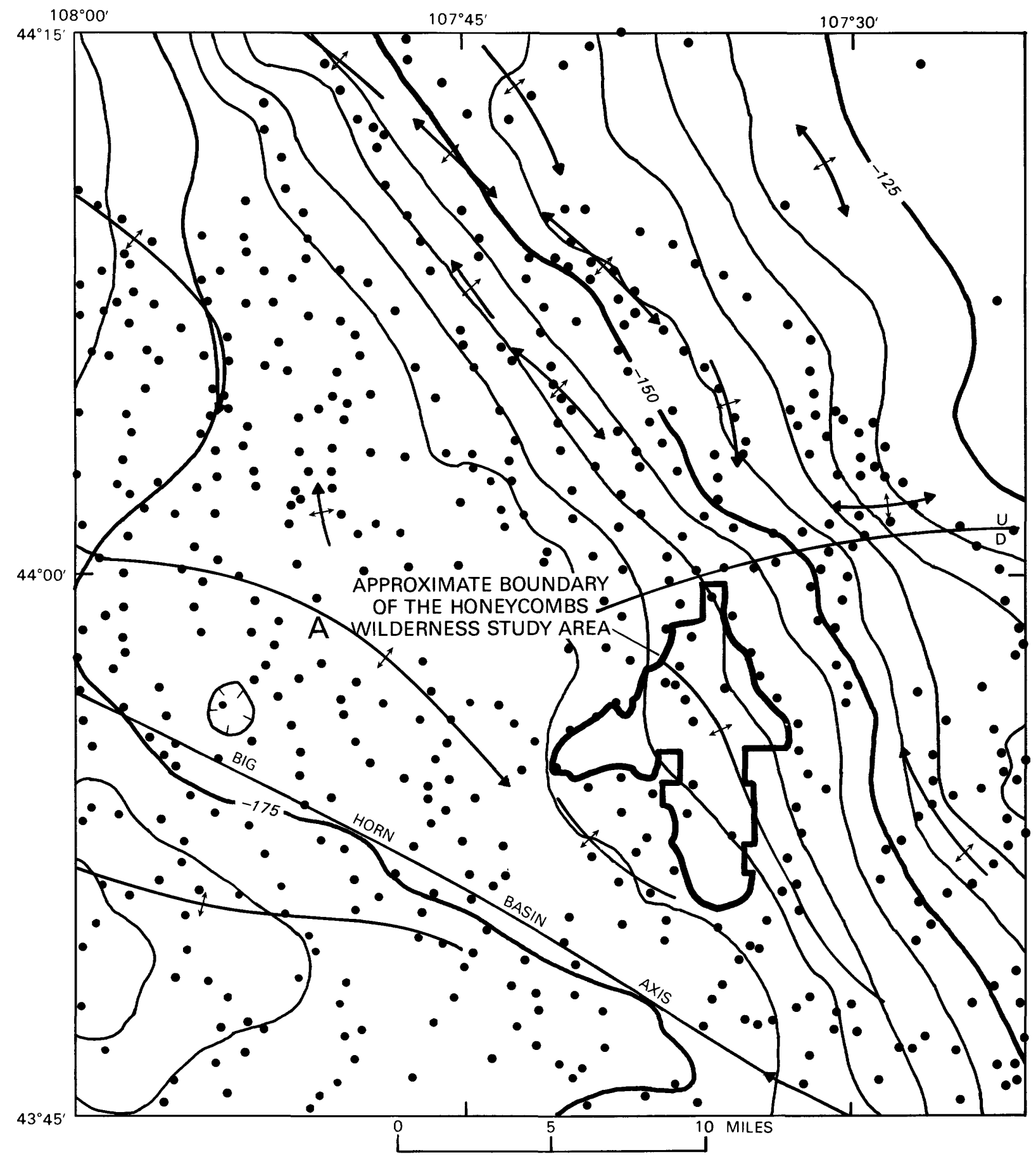

EXPLANATION

- $-150-$ Complete Bouguer gravity anomaly contour -Contour interval 5 milligals. Hachures indicate closed area of lower gravity values

- Gravity station

A Gravity high discussed in text

$\frac{U}{D}$ Fault-U, upthrown side; D, downthrown side

$\longleftarrow$ Anticline-Showing direction and plunge of axis

Figure 6. Complete Bouguer gravity anomaly and generalized structure map of the Honeycombs Wilderness Study Area, Wyoming. 


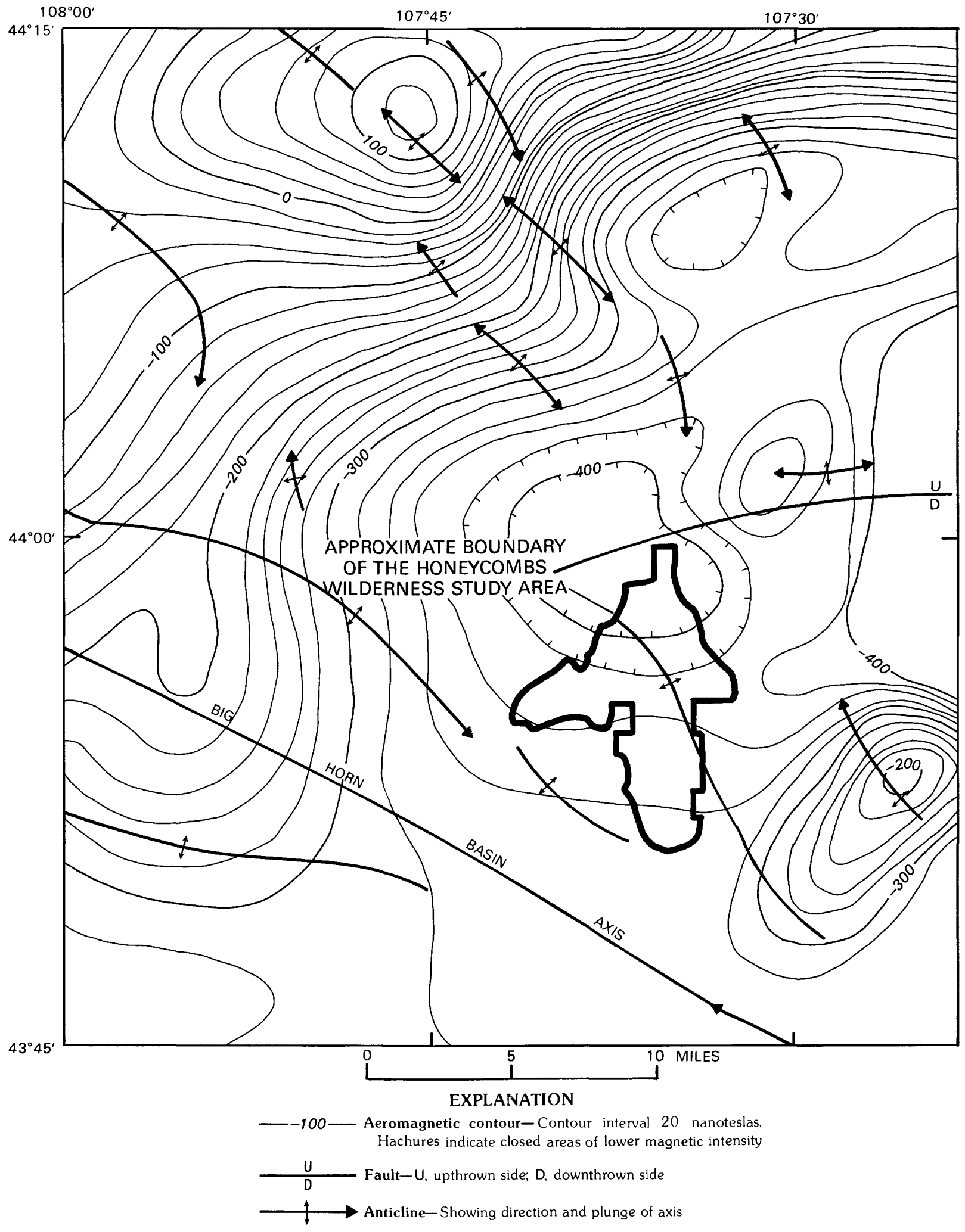

Figure 7. Residual intensity magnetic anomaly and generalized structure map of the Honeycombs Wilderness Study Area, Wyoming. 
The exact boundaries of these facies changes in the subsurface are not well established south of the Cottonwood Creek field. Reservoir characteristics indicate a favorable potential for domal accumulations of oil in the Tensleep Sandstone near and south of the Cottonwood Creek oil field (U.S. Bureau of Land Management, 1986).

\section{Coal}

Fort Union Formation coal beds are exposed within the study area and were investigated and tested (see the section on "Appraisal of Identified Resources"). They are considered to be too thin and too impure to be an economic resource at this writing. Coal beds in the Lance Formation just outside the study-area boundary dip beneath the area so that the thicker Mesozoic coals probably underlie northeastern and southeastern parts of the study area at depths of 50-500 ft. Therefore, these areas have a moderate resource potential with certainty level B for subsurface coal deposits. Mesozoic coal was mined about $1 \mathrm{mi}$ east of the area, at Big Cedar Ridge.

\section{Industrial Minerals}

The mineral resource potential for sand and gravel, sandstone, and mudstone with industrial applications is moderate with level-C certainty along the western and northern edges of the study area. The geologic environment of the study area is favorable for the accumulation of local small deposits of poorly graded sand and gravel in flood-plain terraces, as active stream alluvium along larger streams, and as higher remnants of Pliocene and Pleistocene(?) terraces of boulder gravel near the eastern margins of the study area. This material, if washed, might be suitable locally for road base or other foundation structure when permeability is an important factor. Abundant deposits of well-graded, fine-grained mudstone of the Fort Union are present. These mudstone deposits might be locally suitable for dam core or other structures where low bearing strength and impermeability are not undesirable factors. Bloating characteristics of individual samples of mudstone should be determined before use. Most sandstones of the Fort Union in the study area are either too poorly indurated or contain too much ferruginous cement to be usable as dimension stone. Alternatively, they appear to have good splitting characteristics, are locally rippable, and could be used locally as flagstone, hearth stone, riprap, or cover, where bearing-strength requirements are minimal and eventual rust staining is esthetically acceptable.

\section{Uranium}

The geologic setting of the study area and geochemical data suggest low mineral resource potential with level-C certainty for uranium in near-surface roll- front or peneconcordant deposits in the study area. The lower part of the Fort Union Formation in the study area contains the lithologic association of lenticular channel sandstone, coal, and siltstone that hosts roll-front-type uranium deposits in strata of similar age in other Wyoming sedimentary basins. Rock and stream-sediment samples derived from the lower part of the Fort Union Formation in the study area contain only background concentrations of uranium (less than $1 \mathrm{ppm}$ ). Higher concentrations of $4.5 \mathrm{ppm}$ and $11 \mathrm{ppm}$ uranium in rock samples from isolated sites in the upper part of the formation do not indicate the presence of deposits. Uranium deposits of the roll-front type, though characteristic of parts of the Fort Union Formation in the Powder River basin, have not been reported in the Bighorn Basin (Harris, 1983). To the east of the study area, both the Packer deposit, a peneconcordant uranium deposit in the Upper Jurassic Morrison Formation in sec. 21, T. 47 N., R. 89 W., and the Dugout Creek deposit, a paleobeach-placer thorium deposit in the Upper Cretaceous Mesaverde Formation in sec. 35, T. 46 N., R. $89 \mathrm{~W}$., lie on a north-trending strike belt of uranium and thorium deposits. These deposits and associated anomalously high radioactivity are along strike trends in Mesozoic strata about $3 \mathrm{mi}$ east of the study area. These hosting strata are as much as several thousand feet under the surface of the study area. There are insufficient data to determine whether these strata are mineralized in the subsurface of the study area.

\section{Metals}

Available geologic and geochemical data suggest that there is no mineral resource potential for metals in the Honeycombs Wilderness Study Area, with a certainty level of D. The geologic environment is one of semiindurated, largely fine grained sedimentary strata with no known plutonic sources for metals or mineralizing fluids. Abundantly mineralized rock was not identified at the surface during field work. The source of a detectable silver value of $0.5 \mathrm{ppm}$ in one sample is not known but is not thought to indicate extensive silver mineralization. Concentrations of barium, zirconium, and titanium in heavy-mineral fractions of panned-concentrate samples are high but not anomalous. These high concentrations are the result of concentration by panning as well as mechanical erosion and weathering in the active stream alluvium of barite, zircon, rutile and ilmenorutile, but these concentrations, though noted, do not constitute potential resources. Samples of bedrock otherwise show generally normal background values for other geochemically analyzed metals.

There has been speculation that the Tertiary rocks of the study area might contain titanium deposits. Titanium minerals in paleobeach placers in the Mesa- 
verde Formation, which is unconformably overlain by basal Fort Union rocks south of the study area, may have been eroded and spread westward by earliest Tertiary streams, only to be reconcentrated in clastic delta-front deposits in this part of the Bighorn Basin. However, several geochemical surveys (by the USGS, USBM, and BLM) yielded only background-level values. Titanium minerals could be reconcentrated at depth beneath the study area, but currently there are insufficient data to support or refute this possibility. The potential for titanium resources is unknown, with a certainty level of $A$, at depth beneath the study area. However, if resources are present, their development is unlikely in the foreseeable future due to the prospective costs of discovering and extracting them compared to surficial titanium resources elsewhere.

\section{Geothermal Resources}

There is no potential for geothermal resources in the study area, with certainty level D. No designated geothermal areas are near the study area, and no geothermal leases are in or adjacent to the study area. Within the thick section of sedimentary strata in the subsurface of the study area, no plutonic or volcanic sources of heat are known. Heat-generating basement sources such as highly radioactive granite have not been identified underneath the study area but would lie below the surface at depths approaching $3 \mathrm{mi}$.

\section{REFERENCES CITED}

Allison, M.L., 1983, Deformation styles along the Tensleep fault, Bighorn Basin, Wyoming, in Boberg, W.W., ed., Geology of the Bighorn Basin: Wyoming Geological Association, 34th Annual Field Conference, Guidebook, p. 63-75.

1984, Structural controls on a stratigraphic trap-The Cottonwood Creek field, Bighorn Basin, Wyoming, in Goolsby, Jim, and others, eds., The Permian and Pennsylvanian geology of Wyoming: Wyoming Geological Association, 35th Annual Field Conference, Guidebook, p. 355-367.

Almquist, C.L., 1987, Mineral investigation of the Honeycombs Wilderness Study Area (WY-010-221), Washakie County, Wyoming: U.S. Bureau of Mines Open File Report MLA 20-87, 10 p.

American Society for Testing and Materials, 1980, Gaseous fuels; coal and coke; atmospheric analysis: Annual Book of ASTM Standards, pt. 26, 936 p.

Boberg, W.W., ed., 1983, Geology of the Bighorn Basin: Wyoming Geological Association, 33rd Annual Field Conference, Guidebook, 274 p.

Bown, T.M., 1975, Paleocene and Lower Eocene rocks in the Sand Creek-No Water Creek area, Washakie County, Wyoming: Wyoming Geological Association, 27th Annual Field Conference, Guidebook, p. 55-61.
Bugrov, V.A., and Shalaby, I.M., 1975, Geochemical prospecting in the eastern desert of Egypt, in Elliott, I.L., and Fletcher, W.K., eds., Geochemical exploration, 1974: Elsevier, p. 523-530.

Burke, C.A., and Thomas, H.D., 1956, The Goose Egg Formation (Permo-Triassic) of eastern Wyoming: Geological Survey of Wyoming Report of Investigations 6, $21 \mathrm{p}$.

Cordell, Lindreth, Keller, G.R., and Hildenbrand, T.G., 1982, Complete Bouguer gravity anomaly map of the Rio Grande rift, Colorado, New Mexico, and Texas: U.S. Geological Survey Geophysical Investigations Map GP-949, scale 1:1,000,000.

Crock, J.G., Briggs, P.H., Jackson, L.L., and Lichte, F.E., 1987, Analytical methods for the analysis of stream sediments and rocks from wilderness study areas: U.S. Geological Survey Open-File Report 87-84, 35 p.

Geodata International, 1980, Aerial radiometric and magnetic survey, Thermopolis National Topographic Map, Wyoming, Rocky Mountains, 1979: Report GJBX-64-80, includes microfiche, maps scale 1:500,000. Available from Books and Open-file Reports Section, U.S. Geological Survey, Federal Center, Box 25425, Denver, CO 80225 .

Glass, G.B., Westervelt, Katherine, and Oviatt, C.G., 1975, Coal mining in the Bighorn of Wyoming, in Exum, F.A., and George, G.R., eds., Geology and mineral resources of the Bighorn Basin: Wyoming Geological Association Guidebook, 27th Annual Field Conference, p. 221-228.

Goudarzi, G.H., compiler, 1984, Guide to the preparation of mineral survey reports on public lands: U.S. Geological Survey Open-File Report 84-787, 42 p.

Grimes, D.J., and Marranzino, A.P., 1968, Direct-current arc and alternating-current spark emission spectrographic field methods for the semiquantitative analysis of geologic materials: U.S. Geological Survey Circular 591, 6 p.

Harris, R.E., 1983, Uranium and thorium in the Bighorn Basin, in Boberg, W.W., ed., Geology of the Bighorn Basin: Wyoming Geological Association, 34th Annual Field Conference, Guidebook, p. 171-177.

Hartman, J.E., 1986, Paleontology and biostratigraphy of the lower part of Polecat Bench Formation, southern Bighorn Basin, Wyoming: University of Wyoming Contributions to Geology, v. 24, no. 1, p. 11-64.

Horn, G.H., 1963, Geology of the east Thermopolis area, Hot Springs and Washakie Counties, Wyoming: U.S. Geological Survey Oil and Gas Investigations Map OM-213, scale $1: 48,000$.

International Association of Geodesy, 1971, Geodetic Reference System, 1967: International Association of Geodesy Special Publication 3, 116 p.

Jepsen, G.L., 1940, Paleocene faunas of the Polecat Bench Formation, Park County, Wyoming, Part 1: American Philosophical Society Proceedings, v. 83, no. 2, p. 217-340.

Larsen, C.E., Hill, R.H., Kulik, D.M., Brown, M.K., and Scott, D.C., 1988, Mineral resources of the Cedar Mountain 
Wilderness Study Area, Washakie and Hot Springs Counties, Wyoming: U.S. Geological Survey Bulletin 1756-B.

Love, J.D., Christiansen, A.C., Earle, J.L., and Jones, R.W., 1978, Preliminary geologic map of the Arminto $1^{\circ} \times 2^{\circ}$ quadrangle, central Wyoming: U.S. Geological Survey Open-File Report 78-1089, 10 p., map scale 1:250,000.

Miller, J.A., 1957, Titanium, a materials survey: U.S. Bureau of Mines Information Circular 7791, 202 p.

O'Leary, R.M., and Meier, A.L., 1986, Analytical methods used in geochemical exploration, 1984: U.S. Geological Survey Circular 948, $48 \mathrm{p}$.

Overstreet, W.C., and Marsh, S.P., 1981, Some concepts and techniques in geochemical exploration, in Skinner, B.J., ed., Economic Geology-Seventy-Fifth Anniversary Volume 1905-1980: Economic Geology Publishing Company, p. 775-805.

Palache, Charles, Berman, Harry, and Frondell, Clifford, 1951, The system of minerology of James Dwight Dana and Edward Salisbury Dana, Yale University, 1837-1892, v. 2 (7th ed.): New York, Wiley, 1124 p.

Parker, S.E., and Jones, R.W., 1983, Influence of faulting on Upper Cretaceous-Lower Tertiary deposition, Bighorn Basin, Wyoming, in Boberg, W.W., ed., Geology of the Bighorn Basin: Wyoming Geological Association, 34th Annual Field Conference, Guidebook, p. 137-162.

Pedry, J.J., 1975, Tensleep fault trap, Cottonwood Creek field, Washakie County, Wyoming: Wyoming Geological Association, 27th Annual Field Conference, Guidebook, p. 211-220.

Plouff, Donald, 1977, Preliminary documentation for a FORTRAN program to compute gravity terrain corrections based on topography digitized on a geographic grid: U.S. Geological Survey Open-File Report 77-535, 45 p.
Spencer, C.W., and Powers, R.B., 1982 (1984), Petroleum potential of wilderness lands, Wyoming: U.S. Geological Survey Miscellaneous Investigations Series Map I-1547, scale 1:1,000,000, accompanied by U.S. Geological Survey Circular 902-M.

U.S. Bureau of Land Management, 1986, Draft wilderness environmental impact statement for the Washakie Resource Area: Available from U.S. Bureau of Land Management, Worland District Office, P.O. Box 119, Worland, WY, 82401, 141 p.

U.S. Bureau of Mines and U.S. Geological Survey, 1980, Principles of a resource/reserve classification for minerals: U.S. Geological Survey Circular 831, 5 p.

U.S. Defense Mapping Agency, Aerospace Center, 1974, World Relative Gravity Reference Network, North America, Part 2: Defense Mapping Agency Aerospace Center Reference Publication 25, with supplement updating Gravity Standardization Net, 1971, 1,635 p.

Ver Ploeg, A.J., 1985, Tectonic map of the Bighorn Basin, Wyoming: Wyoming Geological Survey Open-File Report 85-11, scale 1:250,000.

Wing, S.L., and Bown, T.M., 1985, Fine-scale reconstruction of Late Paleocene-Early Eocene paleogeography in the Bighorn Basin of northern Wyoming, in Flores, R.M., and Kaplan, S.S., eds., Cenozoic paleogeography of the west-central United States: Denver, Colo., Rocky Mountain Section, Society of Economic Paleontologists and Mineralogists, p. 93-105.

Wood, G.H., Jr., Kehn, T.M., Carter, M.D., and Culbertson, W.C., 1983, Coal resource classification system of the U.S. Geological Survey: U.S. Geological Survey Circular $891,65 \mathrm{p}$.

Woodruff, E.G., 1908, The coal fields in the southeastern part of the Bighorn Basin, Wyoming: U.S. Geological Survey Bulletin 381, p. 170-185. 
. 
APPENDIX 


\title{
DEFINITION OF LEVELS OF MINERAL RESOURCE POTENTIAL AND CERTAINTY OF ASSESSMENT
}

\author{
Definitions of Mineral Resource Potential
}

LOW mineral resource potential is assigned to areas where geologic, geochemical, and geophysical characteristics define a geologic environment in which the existence of resources is unlikely. This broad category embraces areas with dispersed but insignificantly mineralized rock as well as areas with few or no indications of having been mineralized.

MODERATE mineral resource potential is assigned to areas where geologic, geochemical, and geophysical characteristics indicate a geologic environment favorable for resource occurrence, where interpretations of data indicate a reasonable likelihood of resource accumulation, and (or) where an application of mineral-deposit models indicates favorable ground for the specified type(s) of deposits.

HIGH mineral resource potential is assigned to areas where geologic, geochemical, and geophysical characteristics indicate a geologic environment favorable for resource occurrence, where interpretations of data indicate a high degree of likelihood for resource accumulation, where data support mineral-deposit models indicating presence of resources, and where evidence indicates that mineral concentration has taken place. Assignment of high resource potential to an area requires some positive knowledge that mineral-forming processes have been active in at least part of the area.

UNKNOWN mineral resource potential is assigned to areas where information is inadequate to assign low, moderate, or high levels of resource potential.

NO mineral resource potential is a category reserved for a specific type of resource in a well-defined area.

\section{Levels of Certainty}

\begin{tabular}{|c|c|c|c|}
\hline \multirow{4}{*}{$\begin{array}{l}\text { UNKNOWN } \\
\text { POTENTIAL }\end{array}$} & $\begin{array}{l}\text { H/B } \\
\text { HIGH POTENTIAL }\end{array}$ & $\begin{array}{l}\text { H/C } \\
\text { HIGH POTENTIAL }\end{array}$ & $\begin{array}{l}\text { H/D } \\
\text { HIGH POTENTIAL }\end{array}$ \\
\hline & $\begin{array}{l}\text { M/B } \\
\text { MODERATE POTENTIAL }\end{array}$ & $\begin{array}{l}\text { M/C } \\
\text { MODEAATE POTENTIAL }\end{array}$ & $\begin{array}{l}\text { M/D } \\
\text { MODERATE POTENTIAL }\end{array}$ \\
\hline & Low & $\mathrm{L} / \mathrm{C}$ & $\begin{array}{l}\text { L/D } \\
\text { LOW POTENTIAL }\end{array}$ \\
\hline & POTENTIAL & POTENTIAL & $\begin{array}{l}\text { N/D } \\
\text { NO POTENTIAL }\end{array}$ \\
\hline
\end{tabular}

A

B

C

D

LEVEL OF CERTAINTY $\rightarrow$

A. Available information is not adequate for determination of the level of mineral resource potential.

B. Available information suggests the level of mineral resource potential.

C. Available information gives a good indication of the level of mineral resource potential.

D. Available information clearly defines the level of mineral resource potential.

\section{Abstracted with minor modifications from:}

Taylor, R. B., and Steven, T. A., 1983, Definition of mineral resource potential: Economic Geology, v. 78, no. 6, p. $1268-1270$.

Taylor, R. B., Stoneman, R. J., and Marsh, S. P., 1984, An assessment of the mineral resource potential of the San Isabel National Forest, south-central Colorado: U.S. Geological Survey Bulletin 1638, p. 40-42.

Goudarzi, G. H., compiler, 1984, Guide to preparation of mineral survey reports on public lands: U.S. Geological Survey Open-File Report 84-0787, p. 7, 8. 


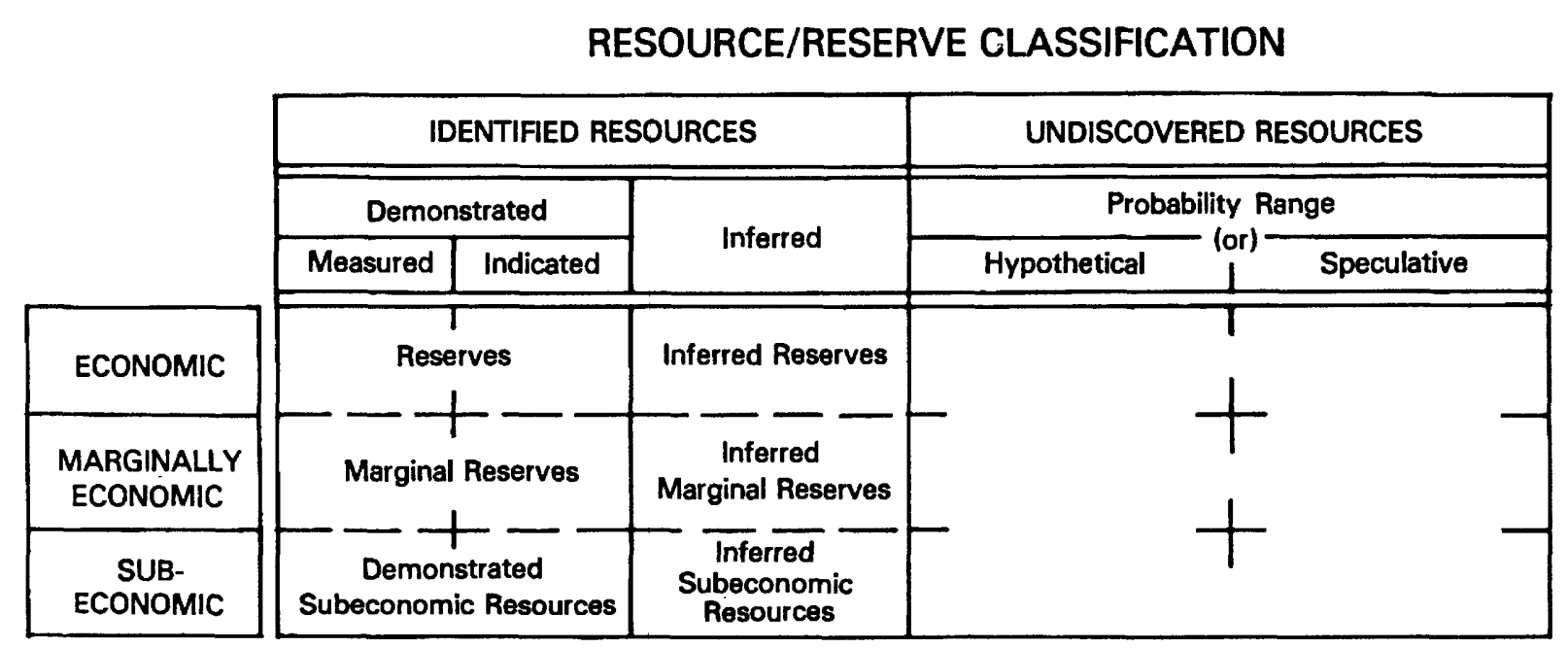

Major elements of mineral resource classification, excluding reserve base and inferred reserve base. Modifled from McKelvey, 1972, Mineral resource estimates and public policy: American Scientist, v.60, p.32-40, and U.S. Bureau of Mines ánd U.S. Geological Survey, 1980, Principles of a resource/reserve classification for minerals: U.S. Geological Survey Circular 831, p.5. 
GEOLOGIC TIME CHART

Terms and boundary ages used in this report

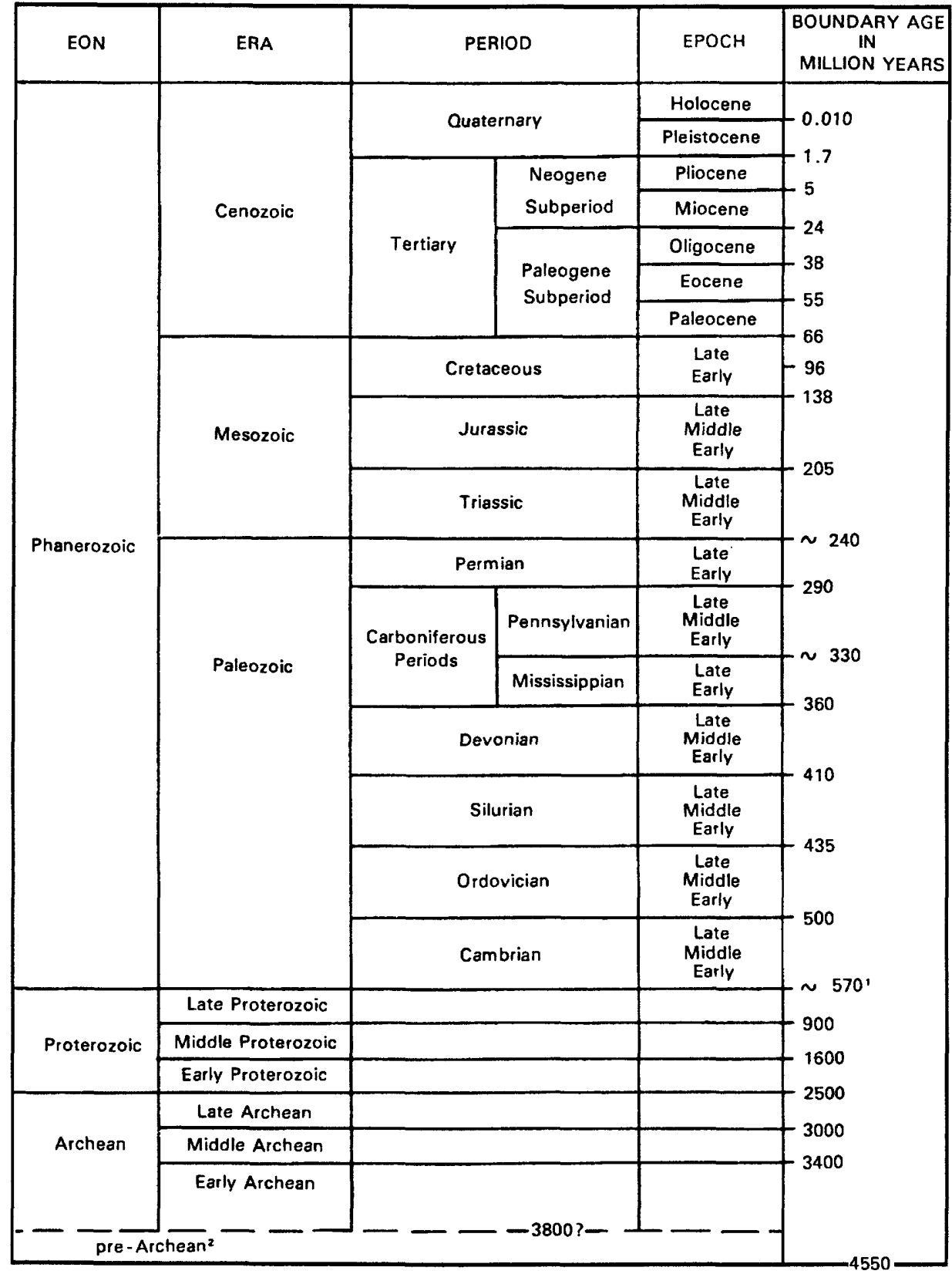

'Rocks older than $\mathbf{5 7 0}$ m.y. also called Precambrian, a time term without specific rank.

2 Informal time term without specific rank. 


\section{SELECTED SERIES OF U.S. GEOLOGICAL SURVEY PUBLICATIONS}

\section{Perlodicals}

Earthquakes \& Volcanoes (issued bimonthly).

Preliminary Determination of Epicenters (issued monthly).

\section{Technical Books and Reports}

Professlonal Papers are mainly comprehensive scientific reports of wide and lasting interest and importance to professional scientists and engineers. Included are reports on the results of resource studies and of topographic, hydrologic, and geologic investigations. They also include collections of related papers addressing different aspects of a single scientific topic.

Bulletins contain significant data and interpretations that are of lasting scientific interest but are generally more limited in scope or geographic coverage than Professional Papers. They include the results of resource studies and of geologic and topographic investigations; as well as collections of short papers related to a specific topic.

Water-Supply Papers are comprehensive reports that present significant interpretive results of hydrologic investigations of wide interest to professional geologists, hydrologists, and engineers. The series covers investigations in all phases of hydrology, including hydrogeology, availability of water, quality of water, and use of water.

Circulars present administrative information or important scientific information of wide popular interest in a format designed for distribution at no cost to the public. Information is usually of short-term interest.

Water-Resources Investigations Reports are papers of an interpretive nature made available to the public outside the formal USGS publications series. Copies are reproduced on request unlike formal USGS publications, and they are also available for public inspection at depositories indicated in USGS catalogs.

Open-File Reports include unpublished manuscript reports, maps, and other material that are made available for public consultation at depositories. They are a nonpermanent form of publication that may be cited in other publications as sources of information.

\section{Maps}

Geologic Quadrangle Maps are multicolor geologic maps on topographic bases in $71 / 2$-or 15 -minute quadrangle formats (scales mainly $1: 24,000$ or $1: 62,500$ ) showing bedrock, surficial, or engineering geology. Maps generally include brief texts; some maps include structure and columnar sections only.

Geophysical Investigations Maps are on topographic or planimetric bases at various scales; they show results of surveys using geophysical techniques, such as gravity, magnetic, seismic, or radioactivity, which reflect subsurface structures that are of economic or geologic significance. Many maps include correlations with the geology.

Miscellaneous Investigations Series Maps are on planimetric or topographic bases of regular and irregular areas at various scales; they present a wide variety of format and subject matter. The series also includes 71/2-minute quadrangle photogeologic maps on planimetric bases which show geology as interpreted from aerial photographs. Series also includes maps of Mars and the Moon.
Coal Investigations Maps are geologic maps on topographic or planimetric bases at various scales showing bedrock or surficial geology, stratigraphy, and structural relations in certain coal-resource areas.

Oll and Gas Investigations Charts show stratigraphic information for certain oil and gas fields and other areas having petroleum potential.

Miscellaneous Field Studies Maps are multicolor or black-andwhite maps on topographic or planimetric bases on quadrangle or irregular areas at various scales. Pre-1971 maps show bedrock geology in relation to specific mining or mineral-deposit problems; post-1971 maps are primarily black-and-white maps on various subjects such as environmental studies or wilderness mineral investigations.

Hydrologic Investigations A tlases are multicolored or black-andwhite maps on topographic or planimetric bases presenting a wide range of geohydrologic data of both regular and irregular areas; principal scale is $1: 24,000$ and regional studies are at $1: 250,000$ scale or smaller.

\section{Catalogs}

Permanent catalogs, as well as some others, giving comprehensive listings of U.S. Geological Survey publications are available under the conditions indicated below from the U.S. Geological Survey, Books and Open-File Reports Section, Federal Center, Box 25425. Denver, CO 80225. (See latest Price and Availability List.)

"Publications of the Geologlcal Survey, 1879-1961" may be purchased by mail and over the counter in paperback book form and as a set of microfiche.

"Publications of the Geological Survey, 1962-1970" may be purchased by mail and over the counter in paperback book form and as a set of microfiche.

"Publications of the U.S. Geological Survey, 1971- 1981" may be purchased by mail and over the counter in paperback book form (two volumes, publications listing and index) and as a set of microfiche.

Supplements for 1982, 1983, 1984, 1985, 1986, and for subsequent years since the last permanent catalog may be purchased by mail and over the counter in paperback book form.

State catalogs, "List of U.S. Geological Survey Geologic and Water-Supply Reports and Maps For (State)," may be purchased by mail and over the counter in paperback booklet form only

"Price and Avallability List of U.S. Geological Survey Publications," issued annually, is available free of charge in paperback booklet form only.

Selected coples of a monthly catalog "New Publications of the U.S. Geological Survey" available free of charge by mail or may be obtained over the counter in paperback booklet form only. Those wishing a free subscription to the monthly catalog "New Publications of the U.S. Geological Survey" should write to the U.S. Geological Survey, 582 National Center, Reston, VA 22092.

Note.--Prices of Government publications listed in older catalogs, announcements, and publications may be incorrect. Therefore, the prices charged may differ from the prices in catalogs, announcements, and publications. 

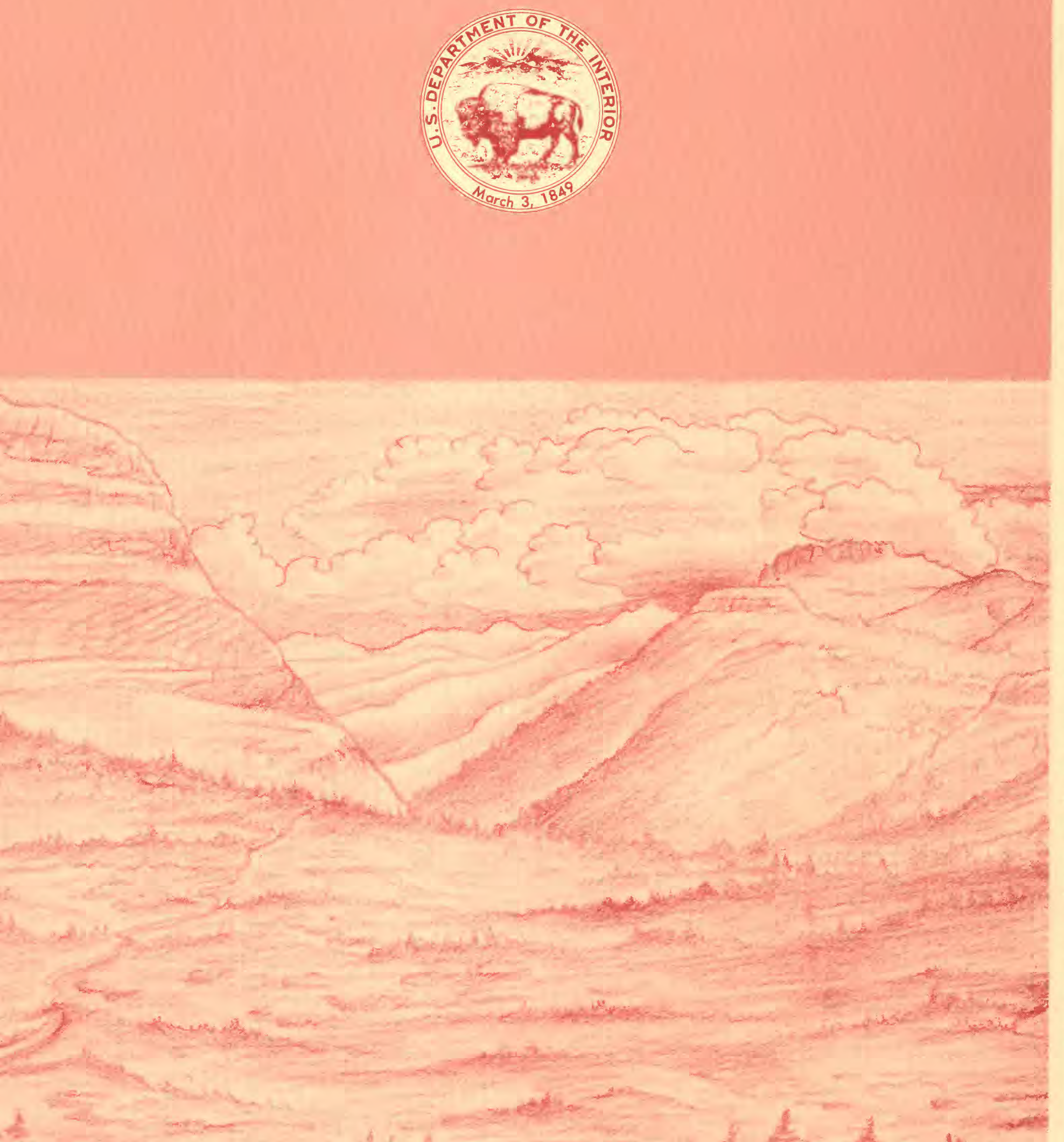